\title{
DYNAMIC-CATENAL PHYTOSOCIOLOGICAL MAPPING OF CORSICA: INDUCTIVE METHODOLOGICAL APPROACH
}

\author{
Pauline DELBOSC ${ }^{1,2}$, Frédéric BIORET ${ }^{l}$, Christophe PANAÏOTIS ${ }^{2}$ \\ ${ }^{1}$ EA 7462 Géoarchitecture, Université de Bretagne Occidentale, UFR Sciences et Techniques, \\ 6 Bd. Victor le Gorgeu, F-29200 Brest, France \\ ${ }^{2}$ Conservatoire Botanique National de Corse, 14 Avenue Jean Nicoli, F-20250 Corte, France \\ e-mail: pauline.delbosc@univ-brest.fr
}

\begin{abstract}
Since the 1970's, the works of Tüxen, Géhu and Rivas-Martínez on the dynamic-catenal phytosociology, allowed a better integratation of vegetation dynamics, by describing more precisely the dynamic trajectories of vegetation series. Since 1973, the context of sigmatist phytosociology extends the conceptual and methodological approach to conservatory management applications of natural and semi-natural vegetations.

Since the end of the $\mathrm{XX}^{\text {th }}$ century, methodologies for the study of vegetation dynamics have been developed according to various typological and cartographical scalar approaches. Logistic and IT tools have contributed significantly to the research work by integrating a spatial dimension into vegetation dynamics.

The national program for the mapping of natural and semi-natural vegetation in France (CarHAB) was launched in 2010 at the initiative of the Ministry of Ecology, Sustainable Development and Energy (MEDDE). Its aim is to establish an Information System on natural and semi-natural vegetations in France, with a view to developing tools for spatial planning, national policies for nature conservation (strategy for the creation of protected areas...) and European obligations (assessment of the state of conservation of habitats of community interest...). This program is focused on the dynamical and landscape phytosociological method or dynamic-catenal phytosociology. This methodology provides a systematic and integrated analysis of all the biotic and abiotic components and the complexity of the ecological systems of the plant landscape.

This paper explains the methodology of mapping vegetation series and geoseries on various synphytosociological map approaches in Europe, whose aim is:

- to develop a precise and pragmatic methodological approach for mapping the series and geosystems of Corsican vegetation at 1: 25000;

- consider the scientific aspects of the design of maps (work scales, typology, map underlayers ...), techniques and semiology of its realization (colours saturation and tone, forms of expression...).
\end{abstract}

Keywords: landscape mapping, vegetation series and geoseries, vegetation landscape, CarHAB program, bioclimatic regions and belts, zonal and azonal units, GIS.

\section{Introduction}

Several vegetation and habitats maps have been published since the $\mathrm{XX}^{\text {th }}$ century [122, 111]. The vegetation mapping of France carried out in 1945 by Gaussen et al. and Ozenda et al. in the Alps [87, 93, 90, 91], the maps of plant communities [44, 45], and more recently [5, 38, $43,72,95]$ demonstrate the interest of vegetation mapping for monitoring and conservation of vegetation, land use and nature conservation issues. 
The map of vegetation/vegetation series of France realized at 1: 200,000 under the direction of Henri Gaussen [41, 42], represented a pioneer work in dynamic mapping of vegetation. Focused on physiognomy and phytogeographical approach, this map uses the main forest species as discriminating criteria of the dynamic stages of vegetation series [91]. For four decades, the mapping work of vegetation has moved towards a phytosociological dynamiccatenal approach, in order to model and spatially represent the structural patterns of vegetation landscape, based on the serial and geoserial units [65]. Mapping of vegetation series and geoseries developed strongly all over Europe [126, 124, 30, 109, 118, 29, 71, 8, 2, 23, 24, 78, 47], but it remains punctual in France [64, 52, 53].

The aim of this article is to expose the methodology for mapping vegetation series and geoseries according to a inductive methodological approach. Considering different synphytosociological mapping approaches of neighbouring countries [124, 2, 24, 113, 78], it is aimed to:

- identify a methodological approach for mapping vegetation series and geoseries of Corsica at 1:25000;

- consider the scientific aspects of the map design (working scales, typologies, ecological cartographic underlayer...), the technical and semiologic aspects of its realization (census, landscape diagnosis ...) [121].

The vegetation series of Corsica, were firstly described according to the principles and concepts of dynamic series of Gaussen (1954) and Ozenda (1964, 1982). Such methods and techniques were used by different authors until the 1980's [39, 52, 4, 53, 92].

In Corsica, the first map of vegetation concerning terrestrial plant communities of Capi Corsu was realized by Molinier (1959, 1962). Mapping experiences have developed strongly in the 1980 's, in order to provide complementary spatial information at synsystematic and phytoecological studies. Corsica has been subject of many mapping work that can be divided into three categories:

- vegetation mapping [54, 74, 107, 94, 99, 79, 100, 101, 102, 115, 96, 116, 80, 17, 103, 81, $106,117,105,119,104,120,18,19,20,97,98,95]$;

- habitat mapping: [86, 21, 34, 33, 35, 137, 135];

- vegetation series mapping (physiognomically sensu Gaussen): Gamisans \& Grüber (1979) on «Vallée du Niolu», and Gamisans et al. (1981b) on «Massif du HautVénacais».

\section{Materials and Methods}

Geographic information system

An important part of our research project is to develop a database to gather the data collected on the field. The definition of a dynamic model is necessary to:

- manage phytosociological, synphytosociological and geosynphytosociological data;

- manage referential typology (phytosociological, synphytosociological and geosynphytosociological levels);

- manage all ecological mapping data (geology, bioclimatology, geomorphology, soil...), vegetation maps (plant community map, habitat map...) and land use (CORINE Land Cover, fires map...).

This database should allow to enter and process the information collected during the 
proceedings of mapping inventories at different levels of integration of the landscape.

Pesaresi et al. (2007) developed a database for Italy, from phytosociological to geoserial levels, based on dynamic relationships between various GIS information tables:

- phytosociological data (phytosociological relevés and phytosociological typology);

- synphytosociological data (synphytosociological relevés and serial typology);

- geosynphytosociological data (geosynphytosociological relevés and geoserial typology).

The database of vegetation series is based on that of Pesaresi et al. (2007) while adapting to the aim of our research project. The main layer of information, on which relations are carried out, is made up of objects "vegetation series" and not "plant communities" objects.

The mapping work was carried out under the ArcGIS $10 \AA$ software. For the realization of GIS, Geodatabase has been established from a database of type "dynamic relationships".

The database is established from two matrices:

- a non-spatial matrix corresponding to synrelevés;

- a spatial matrix on GIS (ArcGIS 10®) which corresponds to polygons of vegetation series.

These two matrix are linked in GIS by the synrelevé number (Fig. 1). This number

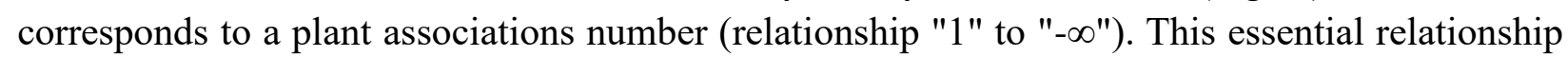
allows to obtain the data inside the polygons where a synrelevé is realized.

Figure 1 shows the information flows of the computer system established in the geodatabase for mapping vegetation series and geoseries. The lines represent the relationships between tables: every relationship is a fundamental component to establish a connection between the attributes of the mapped objects. If a vegetation series can characterize a multitude of polygons, a polygon can contain only one set of vegetation (one to many " 1 - $\infty$ "). Tables 1, 2 and 3 are generated in the first step under Excel ${ }^{\circledR}$ and are, then, imported to ArcGIS software.

\section{Projection system}

The projection system used in mapping to represent on a plan all elements that are located on a sphere, corresponds to the projection coordinate system "RGF93_Lambert_93".

\section{Characteristics of spatial data}

Our aim is to represent spatially sigmetal units that are the expression of ecological and anthropogenic phenomena of vegetation landscape. Their components can be expressed in various forms [31]:

- punctual: object size "0" indicates the location by its coordinates;

- linear: described by a succession of points and a series of coordinate pairs [XY];

- superficial: described by two dimensions that are the area and perimeter, the object

is defined by a succession of coordinate pairs [XY], the first and last pairs being identical.

In our study, we chose to represent the vegetation series and geoseries only by polygons.

\section{Choice of scale}

It makes sense to remember that map object is the corresponding of serial entity observable on field. This fact implies that even if the object and the entity are similar, they may 


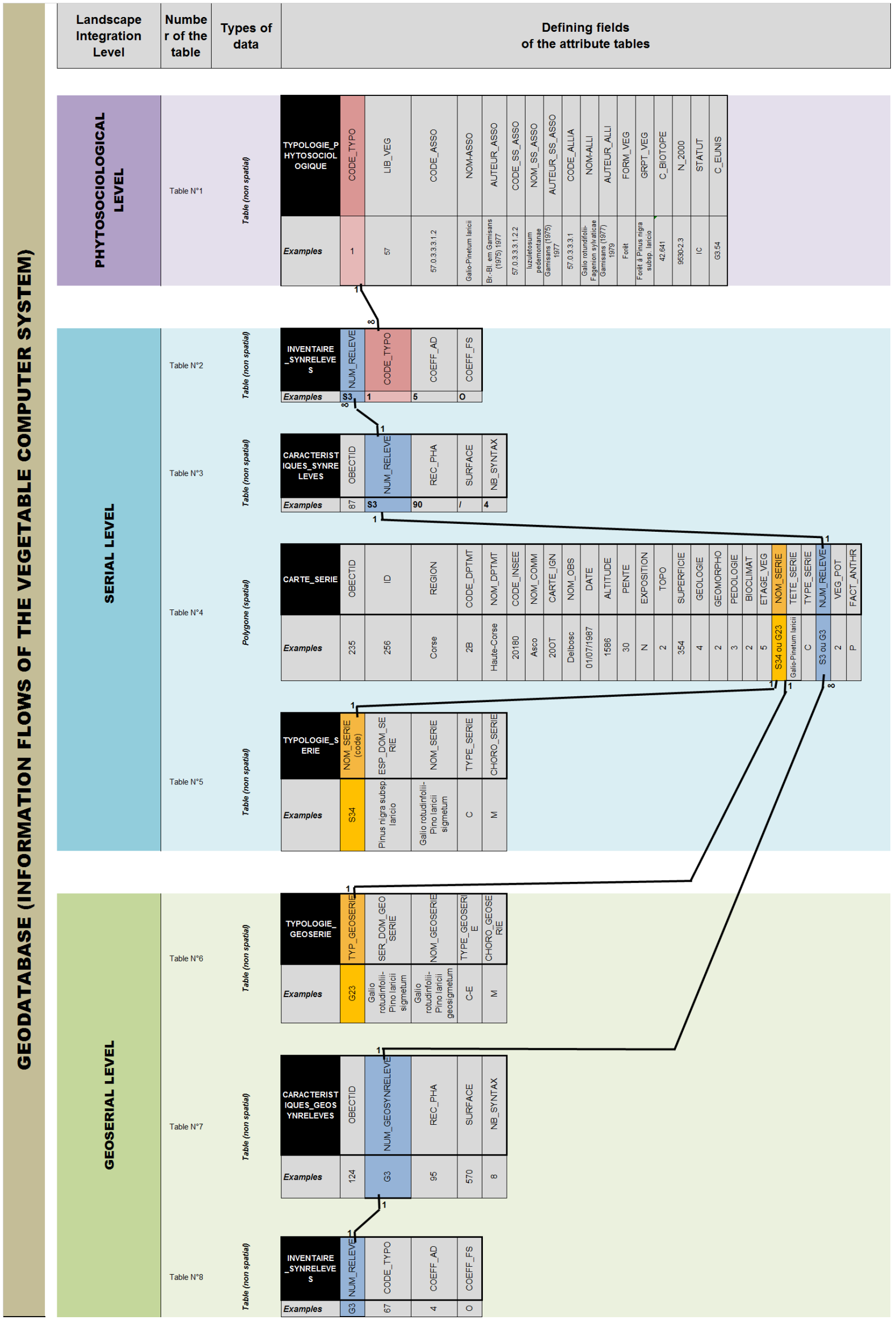

Fig. 1: Scheme of the geodatabase (description of the information flows in the information system of vegetation series). 
not be completely identical, in so far as it is impossible to maintain a physical size and be in a 1: 1 ratio. The choice of a scale depends on the phenomenon to represent and on the size of the smallest object to make it visible on the map [70, 3, 73].

The scale of a map expresses the ratio of the length measured on this map to the corresponding length field measured horizontally $[32,66]$. There are two types of scale $[1,32$, 66]:

- "large scale" means that the fraction has a small denominator, for example 1: $5000(1 \mathrm{~cm}=$ $50 \mathrm{~m}$ ). It is often used to represent phytosociological objects (plant associations).

- "small scale" means that the fraction has a large denominator, 1: 50,000 $(1 \mathrm{~cm}=500 \mathrm{~m})$.

This level of scale is used for mapping synphytosociological or geosynphytosociological units.

Within the CarHAB program, the scale of restitution is $1: 25,000(1 \mathrm{~cm}=250 \mathrm{~m})$. We retain the 1: 4000 for field scale. The scale of capture has, for certain parts of valleys, being greater $(1: 2,500-1: 3,000)$. If this scale is greater than the ground scale, it is above all to refine the contours of the sigmetal objects and not to detour new sigmetal objects. The choice of these two scales was made to obtain a:

- sufficient precision for the spatial representation of sigmetal units;

- complete vision of potential vegetation;

- scale adapted to spatial planning and management.

Inductive methodological approach

Figure 2 shows the three steps for mapping vegetation series.

Definition of environmental compartments (Tessella)

The analysis of the ecological descriptors was carried out with the available map data (Tab. 1).

Table 1 highlights the scaling problems of various ecological descriptors. The restitution scale allows the visualization of vegetation sequence from the sea to the inland. In our project, ecological spatial data at the scales closest to the 1:25,000 scale of restitution were selected.

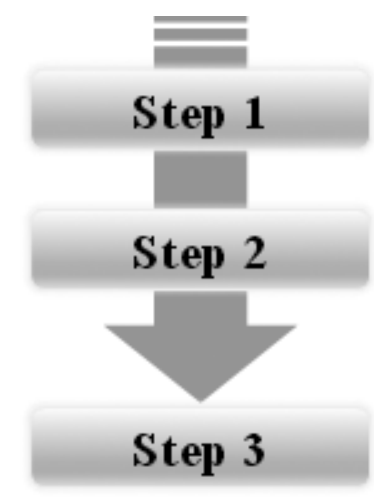

Definition of environmental compartments (Tessella)

Typology of vegetation series

(Dynamic-catenal plant sociology method)

Fig. 2: Scheme of inductive methodological approach 
Table 1: Spatial ecological data available.

\begin{tabular}{c|c|c|c|c}
\hline $\begin{array}{c}\text { Ecological } \\
\text { descriptor }\end{array}$ & Authors & Shape & Scale & Territory \\
\hline Geology & $\begin{array}{c}\text { Rossi \& Rouire } \\
(1980)\end{array}$ & GIS Raster & $1: 250000$ & Corsica \\
\cline { 2 - 5 } Soil & BRGM (2000) & GIS Vector & $1: 50000$ & $\begin{array}{c}\text { Agricultural sectors of } \\
\text { alluvial plains }\end{array}$ \\
\hline Bavreau (2011b) & Paper & $1: 25000$ & Corsica \\
\hline
\end{tabular}

Study areas (geographical entities)

The study areas were selected according to their geographical, ecological and plant originality (Tab. 2, Fig. 3).

Table 2: Features of mapped sites.

\begin{tabular}{|c|c|c|c|c|}
\hline & Sites & Lithology & $\begin{array}{c}\text { Altitude } \\
(\text { min-max }) \\
\end{array}$ & $\begin{array}{c}\text { Area } \\
\text { mapped (ha) }\end{array}$ \\
\hline 1 & Coastal sites (33) & - & Sea level $-100 \mathrm{~m}$ & 1246.8 \\
\hline 2 & Asco valley & Hercynian corsica & $230-2700 \mathrm{~m}$ & 16513.9 \\
\hline 3 & Niolu valley & Hercynian corsica & $345-2700 \mathrm{~m}$ & 22556 \\
\hline 4 & Massif of Haut-Vénacais & Hercynian corsica & $559-2622 \mathrm{~m}$ & 7801 \\
\hline 5 & Cap Corse & Alpine corsica & Sea level - $1350 \mathrm{~m}$ & 32842.1 \\
\hline 6 & $\begin{array}{c}\text { Castagniccia (east part of the } \\
\text { San Pedrone Massif) }\end{array}$ & Alpine corsica & Sea level -1 767 m & 8267.5 \\
\hline 7 & Bonifacio limestone plateau & Alpine corsica & Sea level - $95 \mathrm{~m}$ & 3485.4 \\
\hline 8 & $\begin{array}{c}\text { Plateau of Cuscione (Massif de } \\
\text { l'Incudine) }\end{array}$ & Hercynian corsica & $1105-2129 \mathrm{~m}$ & 6142.9 \\
\hline & & & Total & 98855.6 \\
\hline
\end{tabular}

\section{Typology of geographical entities}

34 vegetation series, 14 minoriseries and 30 geopermaseries have been identified [36]. Three typological units have been added for:

- mountain lakes;

- screes/rocks without vegetation;

\section{Delimitation methods}

Tools such as ecological white underlayer and the physiognomic underlayer [46, 82] developed within CarHAB could not be directly used in order to identify large ecological landscape units. The mapping of vegetation series was therefore based on bioclimatic, geomorphological and phytogeographical mapping data.

Mapping of vegetation series is mainly based on field observations and completed by photo-interpretation extrapolations for inaccessible sectors. The delimitation of vegetation series was divided into three steps (Fig. 4):

- photo-interpretation;

- field observation and verification;

- digitization. 


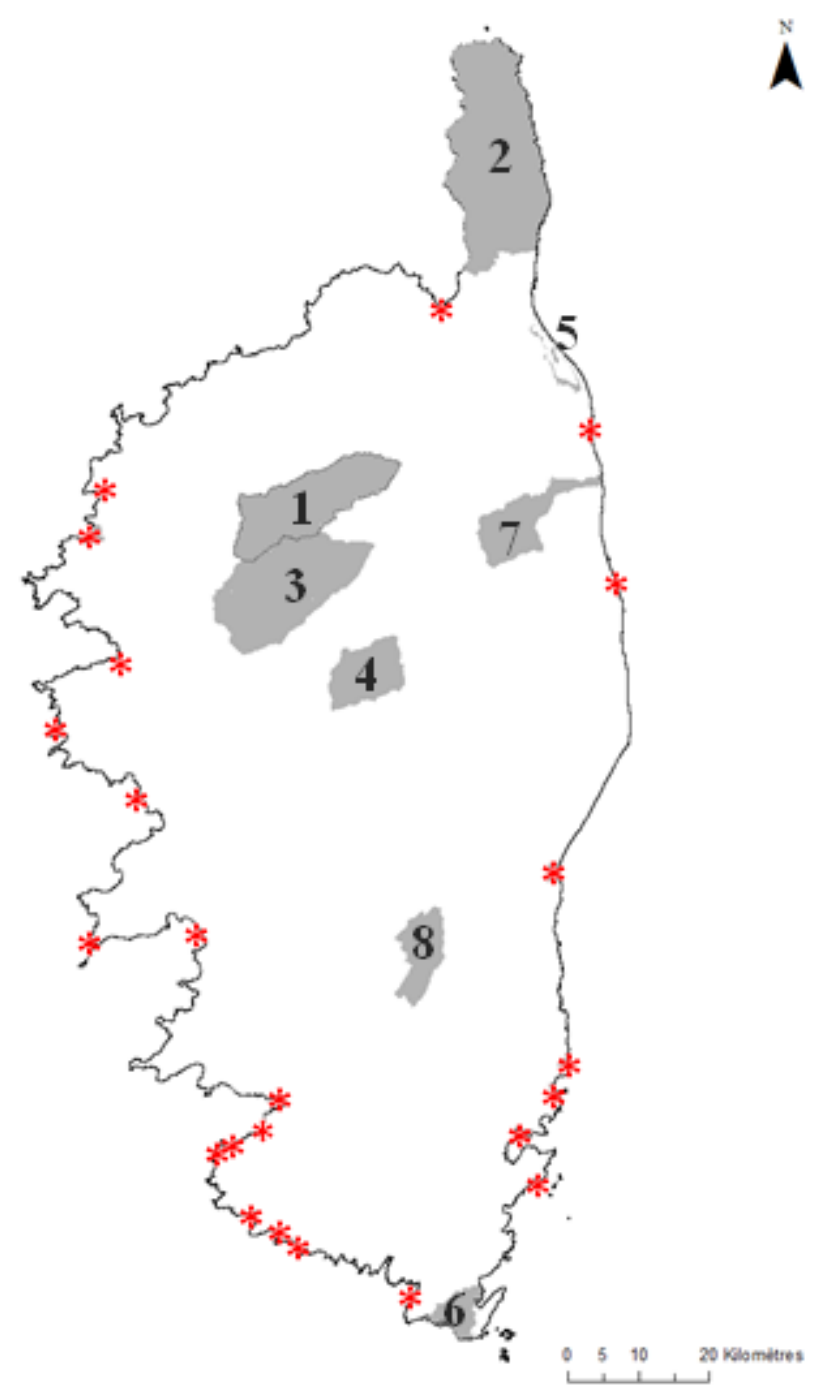

Fig. 3: Study areas. 1 - Asco valley; 2 - Capi Corsu; 3 - Niolu valley; 4 - "Massif du Haut-Vénacais" valley; 5 - "étang de Biguglia» pond; 6 - Bonifacio limestone plateau; 7 - Castagniccia (east part of the «Massif du San Pedrone»; 8 - «Massif de l'Incudine»; * - 30 coastal sites.

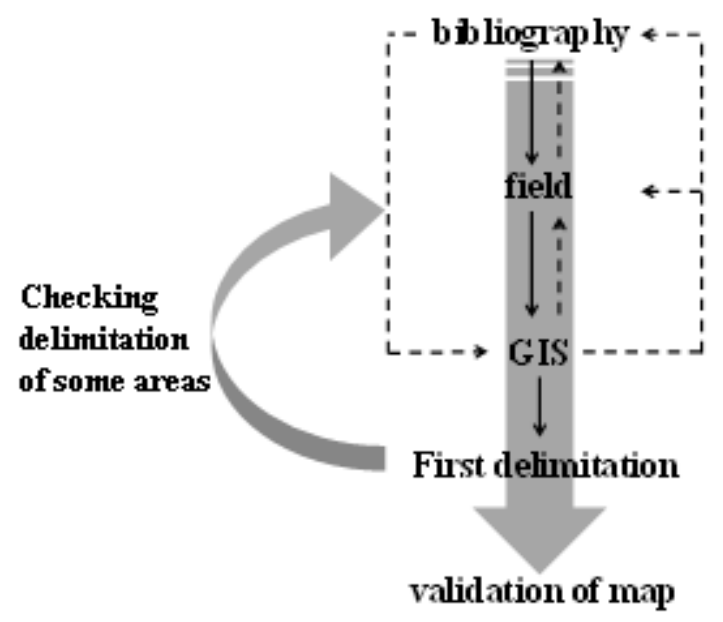

Fig. 4: Method to delimit ecological entities (tessella) 


\section{Minimal map area}

Within the CarHAB program, the area of the smallest mappable object is 0,5 ha for a rendering mapping at 1: 25 000. This minimal area can be discussed because it depends on how the object appears in the landscape: if a 0,5 ha object appears in a linear way, it is not very perceptible on the map; on the other hand, a polygon-like object is apparent on the map at 1: 25000 . For this research project, the mapped minimum area retained is 0,25 ha [36].

\section{Special case of coastal vegetation}

The coastal area constitutes an important part of Corsica [67]. It corresponds to the "landsea" interface and is subject to ecological processes which induce a rapid change in the succession of vegetation, from the sea to the inland. The analysis of specific dynamic processes of coastal areas requires a high-resolution, spatio-temporal mapping approach [72].

The survey scale should be sufficiently precise to establish a boundary between geopermaseries and minoriseries. Individualization of geopermaserial and minoriserial envelopes is based on orthophotographs, topography (BD Alti) and the major physiognomic types of vegetation (thicket and grassland vegetation). The scale of field surveys used for coastal vegetation is 1: 4000. The mapping restitution scale depends on the diversity of mapped objects and their spatial extension (length and width). The choice of the restitution scale for coastal units is 1: 10000 .

\section{Map interpretation of ecological descriptors}

Map of ecological descriptors (geology, soil, bioclimatology, topography) allows a first segmentation of homogeneous ecological entities (or tessellar envelopes). This first division distinguishes three main types of objects:

- coastal azonal units: distinguished by their geomorphological configuration (sandy beaches, pebble beaches, sandy-gravel terraces, salty vases and rocky coasts).

- riparian units: from low-altitude to high-altitude floodplains.

- urbanized areas: constituted by specific polygons.

This division was automatically re-evaluated and re-adjusted in the field due to the scalar disparities of ecological descriptors and sometimes unperceivable orographic effects on orthophotographs (geomorphological and topographical micro-variations).

\section{Field Step}

The field step allows to redefining the delimitation of azonal units, making differences between the serial units types. For climatophilous and edaphoxerophilous series, observations and changes in vegetation made it possible to set a limit between two vegetation series.

\section{Input and scanning procedure}

Mapping of vegetation series implies that only the current potential vegetation is delimited. The map of the series represents only the potentiality of the vegetation and not the dynamic stages which compose them, despite the obvious linkage between the map of vegetation series and the explanatory note. The dynamic stages composing the series are not represented. The delimitation of serial units can be established based on two approaches (Fig. 5):

- the approach following the delimitation of all components of the vegetation series (Fig 5a); 
- the approach following the delimitation of tessellar envelopes (Fig 5b).
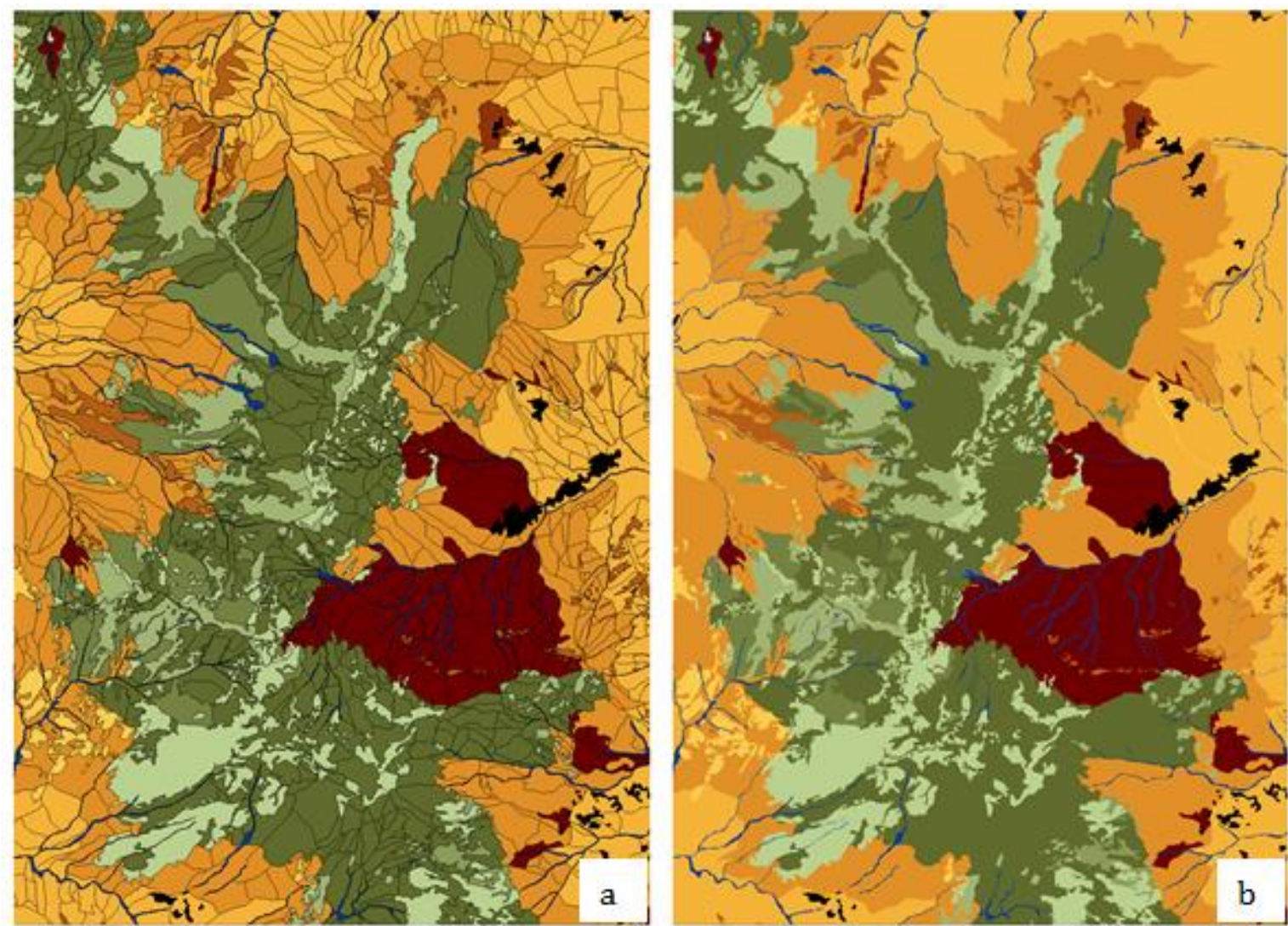

Fig. 5: Example of delimitation of serial objects in Capi Corsu region. a - Delimitation of all components of vegetation series. $b$ - Delimitation of the tessellar envelopes.

Synrelevés were carried out on components of vegetation series and not on tessellas: this choice allows to keep this delimitation only for polygons including synrelevés. Elsewhere, the segmentation of tessellar envelopes was retained. Once the delimitation mode is selected, information collected in the field are imported into an attribute table in GIS that comprises several fields (Tab. 3).

Table 3: Identification of polygons and information on vegetation series: structure of the attribute table.

\begin{tabular}{|c|c|c|c|}
\hline Field & Notice & Type of field & Example \\
\hline OBJECTID & Automatic order number generated by GIS & $\begin{array}{l}\text { Integer } \\
\text { (automatic } \\
\text { number) }\end{array}$ & 147 \\
\hline REGION & $\begin{array}{l}\text { Information about the area in which } \\
\text { the polygon lies (text). }\end{array}$ & text & CORSICA \\
\hline CODE_DPTMT & $\begin{array}{l}\text { Each French department is identified by a } \\
\text { unique number followed by the geographical } \\
\text { code of France: 2A (Corse-du-Sud), 2B } \\
\text { Haute-Corse. }\end{array}$ & text & $2 \mathrm{~B}$ \\
\hline NAME_DPTMT & Name of department & text & Haute-Corse \\
\hline CODE_INSEE & $\begin{array}{l}\text { INSEE code from the website: } \\
\mathrm{http} / / / \text { insee.fr/fr/methodes/nomenclatures/cog/ }\end{array}$ & text & 20276 \\
\hline NAME_COMM & $\begin{array}{l}\text { Optional field indicating the name of the } \\
\text { municipality }\end{array}$ & text & Asco \\
\hline
\end{tabular}




\begin{tabular}{|c|c|c|c|}
\hline NAME_OBS & Name of the observer & text & Pauline Delbosc \\
\hline ORGANISM & UBO and $\mathrm{CBNC}$ & text & UBO-CBNC \\
\hline YEAR & & text & 2012 \\
\hline ALTITUDE & Average altitude in meters & Double real & 1705 \\
\hline SLOPE & Average slope in degrees & Double real & 14 \\
\hline EXPOSITION & $\begin{array}{l}\text { North; South ; East ; West ; South East ; } \\
\text { South West ; North East ; North West }\end{array}$ & text & South-East \\
\hline AREA & The area is indicated in hectares & Double real & 10.07 \\
\hline GEOLOGY & $\begin{array}{l}\text { According to the typology of geological map } \\
\text { of Corsica (Rossi \& Rouire 1980). }\end{array}$ & text & $\begin{array}{l}\text { Alkaline } \\
\text { rhyolites: sills } \\
\text { and domes }\end{array}$ \\
\hline GEOMORPHO & $\begin{array}{l}\text { According to the topographical and } \\
\text { geomorphological typology used for the } \\
\text { approach of vegetation series in Corsica } \\
\text { (Delbosc 2015) }\end{array}$ & text & Slope habitat \\
\hline SOIL & $\begin{array}{l}\text { According to the typology of soils of Corsica } \\
\text { (Synthesis after Favreau } 2002 \text { and Favreau \& } \\
\text { Demartini 2011). }\end{array}$ & text & Cryosols \\
\hline BIOCLIMATE & $\begin{array}{l}\text { According to the typology of bioclimate of } \\
\text { Rias-Martínez (2004) }\end{array}$ & text & Hyper-humid \\
\hline VEG_BELT & $\begin{array}{l}\text { Riparian azonal unit; coastal azonal unit; } \\
\text { thermomediterranean; lower } \\
\text { mesomediterranean; upper } \\
\text { mesomediterranean; supramediterranean; } \\
\text { oromediterranean; cryo-oromediterranean; } \\
\text { subalpine; alpine. }\end{array}$ & text & Oromediterranean \\
\hline CODE_SERIES & & text & 51 \\
\hline NAME_SERIES & Name of series & text & $\begin{array}{c}\text { Climatophilous } \\
\text { Corsican series, } \\
\text { of humid- } \\
\text { hyperhumid } \\
\text { oromediterranean } \\
\text { level with Luzula } \\
\text { pedemontana and } \\
\text { Pinus nigra subsp. } \\
\text { laricio on } \\
\text { crystalline } \\
\text { substrate } \\
\end{array}$ \\
\hline HEAD_SERIES & Corresponds to the head of series & text & $\begin{array}{l}\text { Galio rotundifolii- } \\
\text { Pinetum laricionis } \\
\text { luzuletosum } \\
\text { pedemontanae }\end{array}$ \\
\hline SIGMETUM & Name of sigmetum & text & $\begin{array}{l}\text { Galio rotundifolii- } \\
\text { Pineto laricionis } \\
\text { sigmetum variant } \\
\text { with Luzula } \\
\text { pedemontana }\end{array}$ \\
\hline
\end{tabular}




\begin{tabular}{|c|c|c|c|}
\hline TYPE_SERIES & $\begin{array}{l}\text { Type of landscape unit: Climatophilous, } \\
\text { edaphoxerophilous, edaphohygrophilous... }\end{array}$ & text & Climatophilous \\
\hline NUM_RELEVE & $\begin{array}{l}\text { Enter the relevé number } \\
\text { Specify "VOID" if no relevé }\end{array}$ & text & PADE241 \\
\hline POT_VEG & Potential natural vegetation & text & - \\
\hline ANTHR_FACT & $\begin{array}{l}\text { The field "anthropogenic factors" takes into } \\
\text { account the mode of exploitation of areas: } \\
\text { urbanization (degree of urbanization); grazing; } \\
\text { mowing; agriculture (crops); fire }\end{array}$ & text & grazing and fire \\
\hline
\end{tabular}

\section{Analysis of mapping data}

The interpretation of vegetation landscape can be performed based on two coefficients, reviewed by Foltête \& Tolle in [28]:

- the abundance-dominance coefficient concerns the extension of each component in the landscape and is expressed in relative frequencies.

- the spatial configuration coefficient that describes the shape of mapped objects.

From a phytosociological dynamic-catenal point of view, it is necessary to describe the shape of each series and its catenal positioning in the landscape.

\section{Synthetic mapping step}

The map must include essential informative elements (title reflecting the information contained in the map, information about the data and layers used, scale bar, legend, north arrow).

\section{Legend}

The organization of the legend follows a principle of coherence in order to standardize the structuring of all the typological posts. The legend of vegetation series has been analyzed from several works $[124,77,24,78,111]$. Two main groups of organizations emerge from Italian and Spanish schools.

The construction of the legend corresponds to a structured set of typological posts that:

- take into account large typological units (coastal azonal units, vegetation stages, azonal units...);

- integrate ecological systems of landscape: these systems are essentially valid for coastal units that differ according to their geomorphology (sandy beaches, sandy gravel terraces, pebble beaches, salted vases and rocky coasts);

- highlight different serial units (geopermaseries, minoriseries and series);

- integrate ecology of serial units (climatophilous, edaphoxerophilous, edaphohygrophilous).

\section{Graphic semiology}

Color is a widely used as a visual variable in cartography because it improves document description and contributes to its aesthetic content. In vegetation mapping, the principles of graphic semiology are based on the works of Gaussen [55, 56, 57, 58, 59, 60], Emberger (1961) and Dupias et al. (1965). 
Each color represents an ecological expression of the studied vegetation [59]: warm colors (red and orange) are attributed to dry vegetations of mediterranean types, submediterranean vegetations are represented in yellow and green, and montane in cold colors (blue, purple). This semiologic principles was taken up by Dupias et al. (1965) whose aim was to visualize the arrangement of vegetation according to an altitudinal gradient (vegetation belts). These semiologic principles have been preserved for mapping of vegetation series and geosystems in many European countries: Italy [108, 24, 15, 12, 112, 110, 26, 2, 24, 25, 111]; Spain [134, 124, 76, 136, 78]; Germany [128]; Switzerland [129, 6, 7, 8] and France [40, 52, 53, 20].

The idea of assigning and representing a specific color to a vegetation series corresponds to our objective of dynamic classification where the dynamic stages of series correspond to ecological conditions that determine the head of series [59, 40]. Beyond this approach, no conventional representation or national semiological code has been truly established. It seems important to propose semiological nomenclatural principles to represent landscape units according to vegetation belts and singularities of studied environments:

- Vegetation belts. One color was associated per vegetation belt: warm colors for low-altitude belts (red and orange respectively representing thermomediterranean and mesomediterranean belts); (green for supramediterranean, purple for montaneoromediterranean, green-blue for cryo-oromediterranean, pink forsubalpine and blue-black for alpine belt). The color of each belt is declined into a gradient to differentiate the serial units. A numeric code has been assigned for each serial unit.

- Specificity of coastal units. From a typological point of view, the coastline has been apprehended according to ecological systems (sandy beaches, pebble beaches, rocky coasts ...). This approach has also been used in definition of semiological code: one specific color has been assigned for each ecological system [2, 24, 78].

- Riparian units were distinguished from marshy units by two types of blue: green-blue for marshy units and blue for riparian units.

White has not been used because it does correspond to the absence of vegetation [60]. Heterogeneous textures could have been used for distinguishing mapping objects but this choice limits the reading of map and introduces a quantitative character: textures have not been retained. One of mapping principles stated by Gaussen (1961b) is not to mix color and texture.

\section{Results}

The Asco valley (16513.9 ha) is characterized by 26 serial and geoserial units: 12 series, 4 minoriseries, 8 geopermaseries and two non-vegetable units (urbanized areas (villages, hamlets) and screes/rocks) (Table 6).

This valley is characterized by three major units (Fig. 7):

- (51) Galio rotundifolii-Pineto laricionis sigmetum variant with Luzula pedemontana:

3339.3 ha $(20.2 \%$ of mapping area);

- (25) Galio scabri-Querceto ilicis sigmetum variant with Lathyrus venetus: 2530.5

ha, i.e. $15.3 \%$ of mapping area);

- Junipero oxycedri-Querceto ilicis sigmetum extends over 2456.9 ha $(14.9 \%$ of mapping area). 


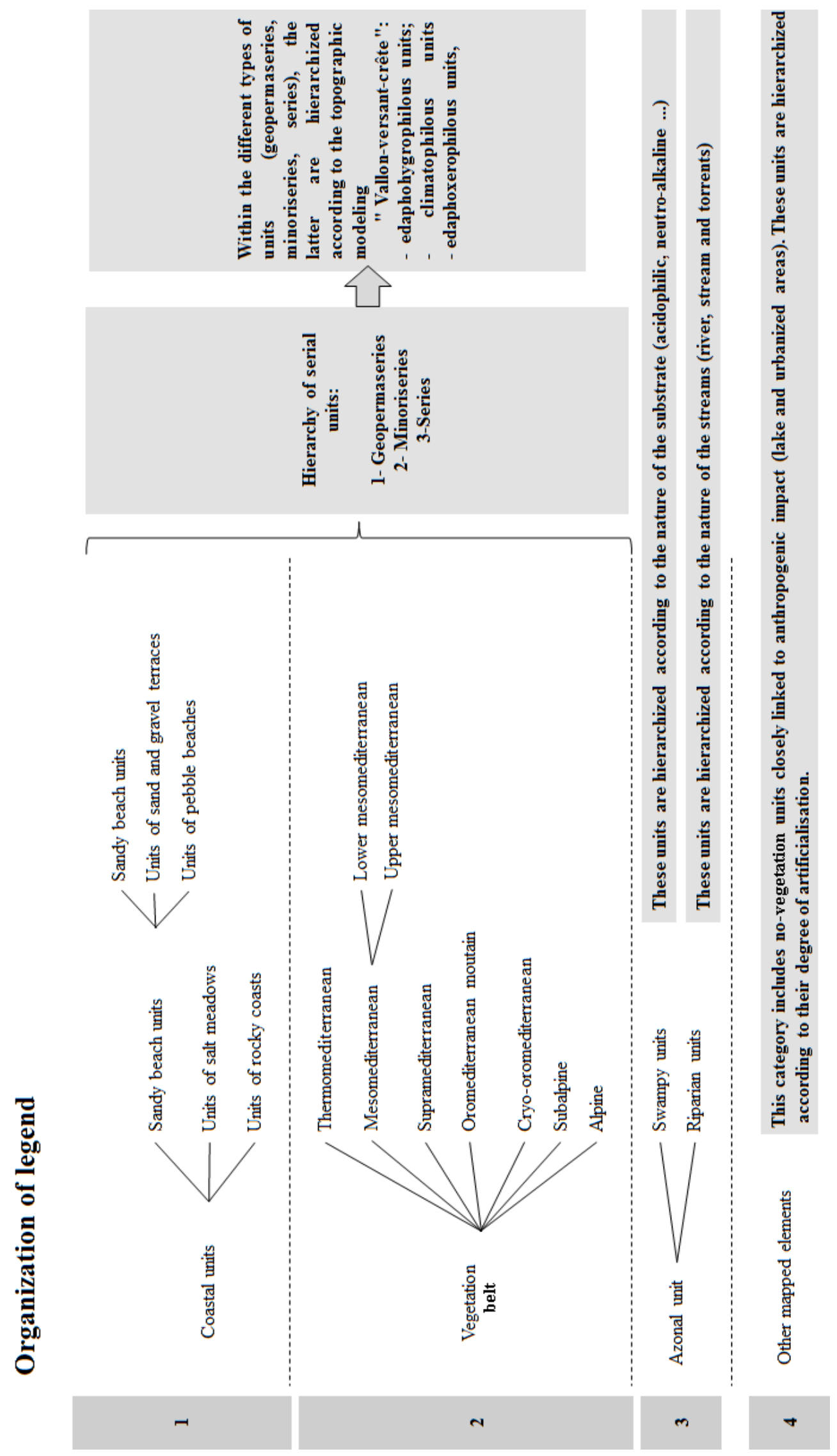

Fig. 6: Principles of organization of the legend. 
Table 4: Typology, area and proportion of different vegetation series and geoseries in the "Asco Valley".

\begin{tabular}{|c|c|c|c|c|c|}
\hline $\begin{array}{c}\text { Code } \\
\text { of } \\
\text { series }\end{array}$ & Name of series & Sigmetum & Vegetation belt & $\begin{array}{r}\text { Area } \\
\text { (ha) }\end{array}$ & $\begin{array}{c}\text { Area } \\
\text { percent } \\
(\%) \\
\end{array}$ \\
\hline 25 & $\begin{array}{l}\text { Oak climatophilous series } \\
\text { on crystalline substrates } \\
\text { (Lathyrus venetus variant) }\end{array}$ & $\begin{array}{c}\text { Galio scabri- } \\
\text { Querceto ilicis } \\
\text { sigmetum (Lathyrus } \\
\text { venetus variant) }\end{array}$ & $\begin{array}{c}\text { Upper } \\
\text { mesomediterranean }\end{array}$ & 2530.5 & 15.3 \\
\hline 28 & $\begin{array}{c}\text { Boxwood and oak } \\
\text { edaphoxerophilous series } \\
\text { of acidophilous alluvial } \\
\text { systems }\end{array}$ & $\begin{array}{c}\text { Buxo } \\
\text { sempervirentis- } \\
\text { Querceto ilicis } \\
\text { sigmetum }\end{array}$ & $\begin{array}{c}\text { Lower } \\
\text { mesomediterranean }\end{array}$ & 611.4 & 3.7 \\
\hline 31 & $\begin{array}{c}\text { Juniper scrub } \\
\text { edaphoxerophilous } \\
\text { minoriseries on } \\
\text { crystalline substrates }\end{array}$ & $\begin{array}{c}\text { Stachydo glutinosae- } \\
\text { Genisteto corsicae } \\
\text { minorisigmetum } \\
\text { (Juniperus } \\
\text { oxycedrus variant) } \\
\end{array}$ & $\begin{array}{c}\text { Upper } \\
\text { mesomediterranean }\end{array}$ & 383.2 & 2.3 \\
\hline 32 & $\begin{array}{c}\text { Juniper scrub } \\
\text { edaphoxerophilous } \\
\text { minoriseries on } \\
\text { crystalline substrates }\end{array}$ & $\begin{array}{l}\text { Stachydo glutinosae- } \\
\text { Genisteto corsicae } \\
\text { minorisigmetum }\end{array}$ & $\begin{array}{c}\text { Lower } \\
\text { mesomediterranean }\end{array}$ & 11.8 & 0.1 \\
\hline 33 & $\begin{array}{l}\text { Chasmophytic and } \\
\text { chomophytic vegetation } \\
\text { geopermaseries on } \\
\text { crystalline rocky cliffs in } \\
\text { mesomediterranean belt }\end{array}$ & $\begin{array}{c}\text { Saxifrago } \\
\text { tridactylitis-Sedeto } \\
\text { stellati } \\
\text { geopermasigmetum }\end{array}$ & $\begin{array}{c}\text { Upper } \\
\text { mesomediterranean }\end{array}$ & 23.7 & 0.1 \\
\hline 38 & $\begin{array}{c}\text { Juniper and oak } \\
\text { climatophilous series on } \\
\text { crystalline substrates }\end{array}$ & $\begin{array}{l}\text { Junipero oxycedri- } \\
\text { Querceto ilicis } \\
\text { sigmetum }\end{array}$ & Supramediterranean & 2456.9 & 14.9 \\
\hline 39 & $\begin{array}{c}\text { Laricio pine } \\
\text { edaphoxerophilous series } \\
\text { on crystalline substrates }\end{array}$ & $\begin{array}{l}\text { Galio rotundifolii- } \\
\text { Pineto laricionis } \\
\text { sigmetum (Erica } \\
\text { arborea variant) }\end{array}$ & Supramediterranean & 1318.6 & 8.0 \\
\hline 42 & $\begin{array}{c}\text { Maple } \\
\text { edaphohygroclinous series } \\
\text { on crystalline substrates }\end{array}$ & $\begin{array}{l}\text { Fraxino orni-Acereto } \\
\text { monspessulani } \\
\text { sigmetum }\end{array}$ & Supramediterranean & 401.2 & 2.4 \\
\hline 44 & $\begin{array}{c}\text { Maple and oak } \\
\text { edaphoanthropophilous } \\
\text { series on crystalline } \\
\text { substrates }\end{array}$ & $\begin{array}{c}\text { Acero } \\
\text { monspessulani- } \\
\text { Querceto ilicis } \\
\text { sigmetum }\end{array}$ & Supramediterranean & 38.4 & 0.2 \\
\hline 45 & $\begin{array}{c}\text { Juniper scrub } \\
\text { edaphoxerophilous } \\
\text { minoriseries on } \\
\text { crystalline substrates }\end{array}$ & $\begin{array}{l}\text { Helichryso italici- } \\
\text { Genisteto salzmannii } \\
\text { minorisigmetum }\end{array}$ & Supramediterranean & 5.8 & 0.04 \\
\hline 47 & $\begin{array}{l}\text { Chasmophytic and } \\
\text { chomophytic vegetation } \\
\text { geopermaseries on } \\
\text { crystalline rocky cliffs } \\
\text { in the } \\
\text { supramediterranean belt }\end{array}$ & $\begin{array}{c}\text { Sedo brevifolii- } \\
\text { Diantheto } \\
\text { godroniani } \\
\text { geopermasigmetum }\end{array}$ & Supramediterranean & 263.4 & 1.6 \\
\hline 51 & $\begin{array}{l}\text { Laricio pine } \\
\text { climatophilous series on } \\
\text { crystalline substrates }\end{array}$ & \begin{tabular}{|c|} 
Galio rotundifolii- \\
Pineto laricionis \\
sigmetum (Luzula \\
pedemontana variant) \\
\end{tabular} & Oromediterranean & 3339.3 & 20.2 \\
\hline
\end{tabular}




\begin{tabular}{|c|c|c|c|c|c|}
\hline 54 & $\begin{array}{l}\text { Chasmophytic and } \\
\text { chomophytic vegetation } \\
\text { geopermaseries on the } \\
\text { crystalline cliffs in the } \\
\text { montane belt }\end{array}$ & $\begin{array}{l}\text { Doronico corsici- } \\
\text { Narthecieto } \\
\text { reverchonii } \\
\text { geopermasigmetum }\end{array}$ & Oromediterranean & 1013.4 & 6.1 \\
\hline 56 & $\begin{array}{l}\text { Juniper scrub } \\
\text { climatophilous } \\
\text { minoriseries on the } \\
\text { crystalline substrates }\end{array}$ & $\begin{array}{c}\text { Paronychio } \\
\text { polygonifoliae- } \\
\text { Armerio multicepitis } \\
\text { minorisigmetum }\end{array}$ & $\begin{array}{l}\text { Cryo- } \\
\text { oromediterranean }\end{array}$ & 634.5 & 3.8 \\
\hline 57 & $\begin{array}{c}\text { Maple } \\
\text { edaphohygroclinous series } \\
\text { on crystalline substrates }\end{array}$ & $\begin{array}{c}\text { Sorbo aucupariae- } \\
\text { Acereto } \\
\text { pseudoplatani } \\
\text { sigmetum }\end{array}$ & Subalpine & 1446.9 & 8.8 \\
\hline 58 & $\begin{array}{l}\text { Geopermaseries on } \\
\text { the crystalline rocks } \\
\text { in the subalpine belt }\end{array}$ & $\begin{array}{c}\text { Geo montani- } \\
\text { Phleeto } \\
\text { brachystachydis } \\
\text { geopermasigmetum }\end{array}$ & Subalpine & 809.5 & 4.9 \\
\hline 59 & $\begin{array}{l}\text { Geopermaseries on the } \\
\text { crystalline screes in the } \\
\text { subalpine belt }\end{array}$ & $\begin{array}{l}\text { Valeriano } \\
\text { rotundifoliae- } \\
\text { Adenostyleto } \\
\text { briquetii } \\
\text { geopermasigmetum }\end{array}$ & Subalpine & 488.2 & 3.0 \\
\hline 60 & $\begin{array}{l}\text { Geopermaseries on the } \\
\text { crystalline rock massifs } \\
\text { in the alpine belt }\end{array}$ & $\begin{array}{c}\text { Acino corsici- } \\
\text { Tanaceteto tomentosi } \\
\text { geopermasigmetum }\end{array}$ & Alpine & 467.5 & 2.8 \\
\hline 61 & $\begin{array}{l}\text { Geopermaseries on the } \\
\text { crystalline screes in the } \\
\text { alpine belt }\end{array}$ & $\begin{array}{c}\text { Doronico } \\
\text { grandiflori-Oxyrieto } \\
\text { digynae } \\
\text { geopermasigmetum }\end{array}$ & Alpine & 8.0 & 0.05 \\
\hline 62 & $\begin{array}{l}\text { Alder edaphohygrophilous } \\
\text { acidophilous Corsican } \\
\text { series on peat substrates }\end{array}$ & $\begin{array}{c}\text { Dryopteridi } \\
\text { carthusianae-Alneto } \\
\text { glutinosae sigmetum }\end{array}$ & Peat azonal unit & 33.7 & 0.2 \\
\hline 67 & $\begin{array}{c}\text { Alder } \\
\text { edaphohygrophilous } \\
\text { riparian series on low } \\
\text { altitude, alluvial } \\
\text { substrates } \\
\end{array}$ & $\begin{array}{l}\text { Eupatorio corsici- } \\
\text { Alneto glutinosae } \\
\text { sigmetum }\end{array}$ & Riparian azonal unit & 62.4 & 0.4 \\
\hline 70 & $\begin{array}{c}\text { Cyclamen and } \\
\text { Phillyrea latifolia } \\
\text { edaphohygrophilous } \\
\text { minoriserie }\end{array}$ & $\begin{array}{l}\text { Cyclamino repandi- } \\
\text { Phillyreeto latifoliae } \\
\text { minorisigmetum }\end{array}$ & Riparian azonal unit & 34.7 & 0.2 \\
\hline 71 & $\begin{array}{l}\text { Alder riparian series on } \\
\text { high altitude, acidic, } \\
\text { alluvial substrates }\end{array}$ & $\begin{array}{c}\text { Athyrio filix- } \\
\text { feminae-Gentianeto } \\
\text { asclepiadeae } \\
\text { sigmetum }\end{array}$ & Riparian azonal unit & 78.4 & 0.5 \\
\hline 74 & $\begin{array}{l}\text { Temporal hygrophilous } \\
\text { geopermaseries on } \\
\text { alluvial substrates }\end{array}$ & $\begin{array}{l}\text { Dittricho viscosae- } \\
\text { Saliceto purpureae } \\
\text { geopermasigmetum }\end{array}$ & Riparian azonal unit & 1.1 & 0.01 \\
\hline 80 & Screes, rocks & - & Riparian azonal unit & 0.4 & 0.003 \\
\hline 81 & Urban areas & - & - & 50.7 & 0.3 \\
\hline & & & Total & 16513.9 & 100 \\
\hline
\end{tabular}


Four other units mark the vegetation landscape of the Asco valley: Sorbo aucupariaeAcereto pseudoplatani sigmetum (1446,9 ha, 8,8\%), Galio rotundifolii-Pineto laricionis sigmetum variant with Erica arborea (1318.6 ha, 8\%), Doronico corsici-Narthecieto reverchonii geopermasigmetum (1013.4 ha, 6.1\%) and Geo montani-Phleeto brachystachydis geopermasigmetum (809.5 ha, 4.9\%).

This valley includes a very peculiar series, endemic of the bottom of the Asco valley: Dryopteridi carthusianae-Alneto glutinosae sigmetum (33.7 ha).

In a regional context, the Asco valley presents a great diversity of serial units, with 24 serial units (excluding the no-vegetation units), which represent $32 \%$ of the sigmetum richness of Corsica. Mapping of vegetation series can be easily transposed into mapping of vegetation belts.

\section{Discussion}

Mapping of vegetation series highlights the complexity of the main structural patterns of Corsica. It helps to a better understanding of sigmacoenotic diversity according to a pluristructural approach, from plant association to vegetation series $[9,10]$.

The simultaneous representation of sigmetum and geosigmetum on the same map involves considering two hierarchical levels of vegetation landscape: the serial and the geoserial levels [124, 2, 24, 78]. It allows the spatial representation of vegetation complexes with an objective point of view.

Mapping of vegetation series integrates a significant number of landscape properties while being synthetic. For a given polygon, the information available in the descriptive note consist in the name of vegetation series and its different dynamic stages. It should however be noted that this map remains little interactive: the information is available only for the polygons that have been synthesized.

As vegetation series mapping represents only the potential natural vegetation, it is a limitation. Even if a GIS technique has been set up to link synrelevés to polygons (join of the main attribute table with the table of synrelevés), it remains limited in so far as this data are only accessible under GIS. The VegFrance national platform aims to organize and structure the typology of French vegetation. This platform constitutes a database related to the mapping of national territory within the framework of CarHAB program [27, 127].

Roux et al. (2015) proposed a specific module of VegFrance called "SYNPHYTO", in order to integrate serial and geoserial data, and link with map data. This project will facilitate the reading of maps by means of dynamic links between the database of synrelevés and geosynrelevés with the maps.

In Corsica, delimitation of vegetation series remains fairly easy as the vegetation zonation is rather well marked from the coastal zone to the alpine belt:

- for coasts, orthophotographs analysis reveals a clear change in physiognomy of vegetation: in general, the anemomorphic vegetations are readible on photographs; the internal limit of coastal vegetation corresponds to anemomorphosed thickets.

- zonal series follow the altitudinal gradient. The main difficulties arise when ruderal or very disturbed vegetation is spread over two vegetation beltss, as it is the case for Pruno spinosae-Rubion ulmifolii. 

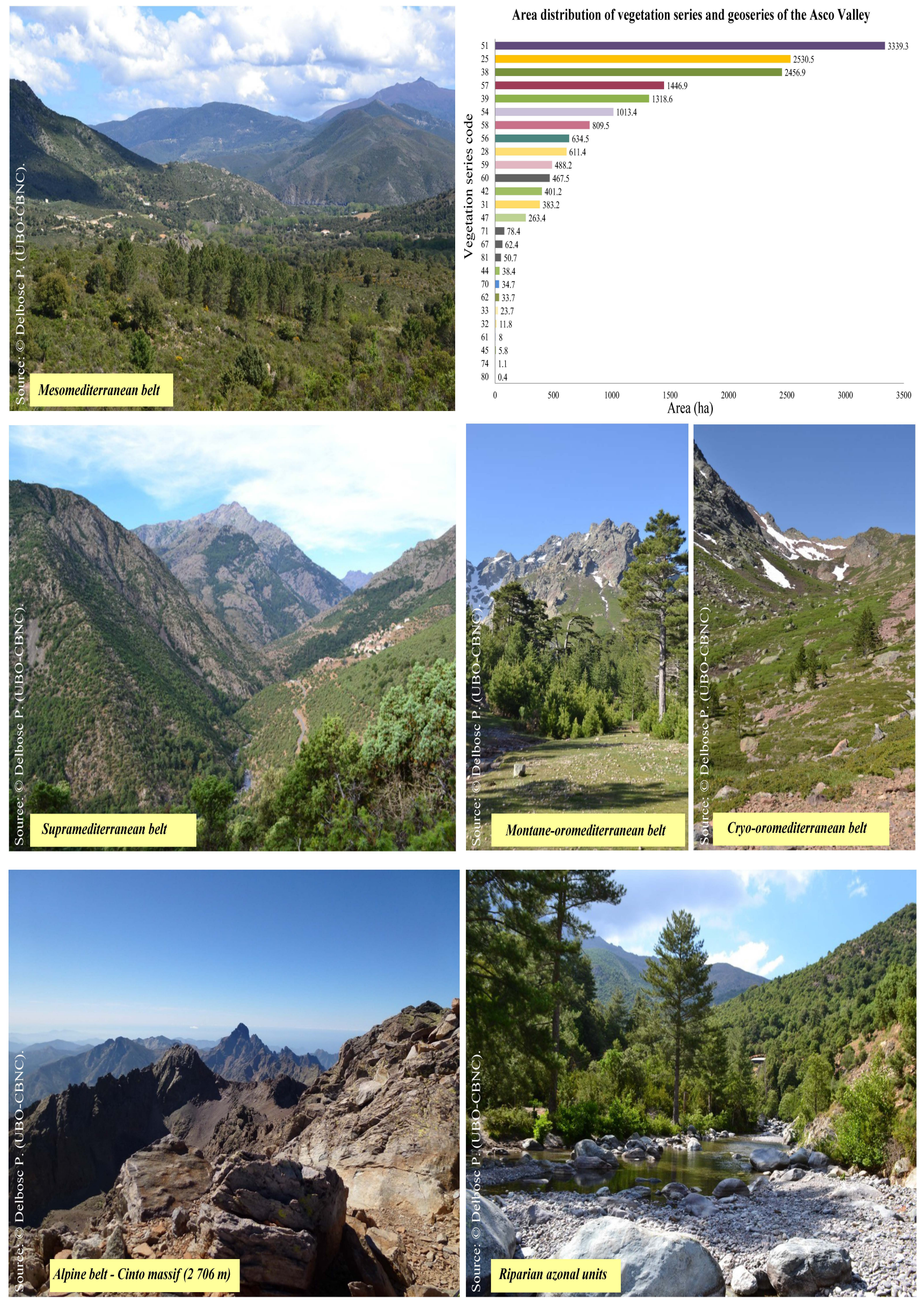

Fig. 7: Distribution of vegetation series and geoseries in the Asco Valley (see the herein folded map and the legend on the next page). 
Vegetation series and geoseries of Corsica Crystalline mountains

\section{ASCO VALLEY}

Rendering Scale: 1 : 80000

Scale of field surveys: $1: 4000$

Size of area: 16526 ha

Inventories: Delbosc P., Bioret F. \& Panaiotis C.

Typology of vegetation series: Delbosc P., Bioret F. \& Panaĩotis C. Entering and digitization of data: Delbosc $P$.

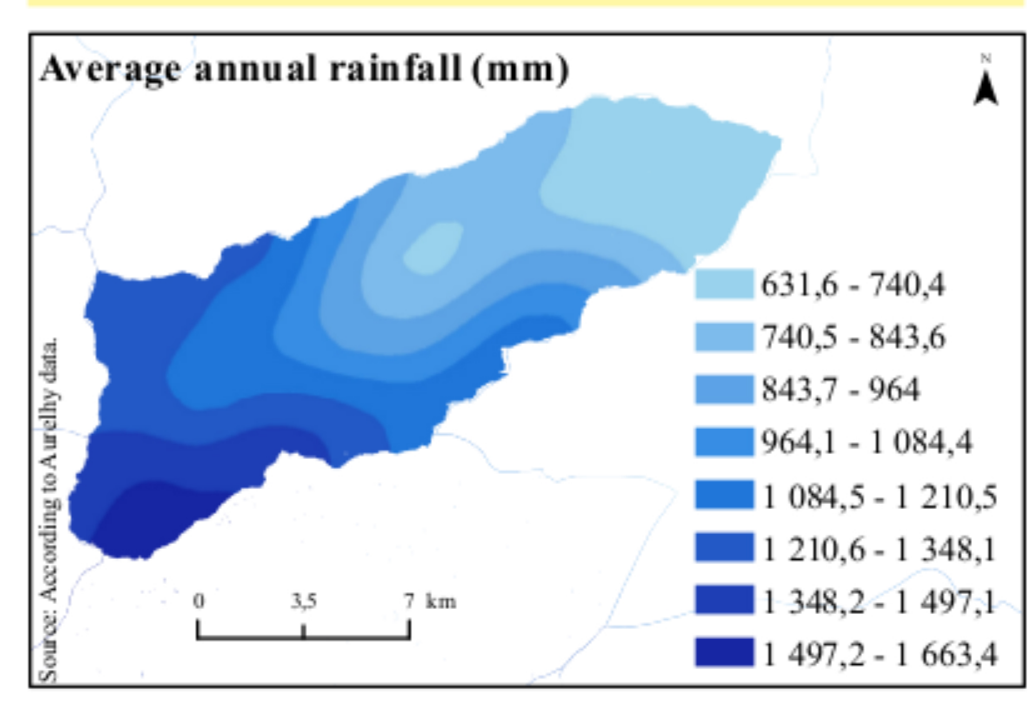

Average annual temperatures $\left({ }^{\circ} \mathrm{C}\right)$

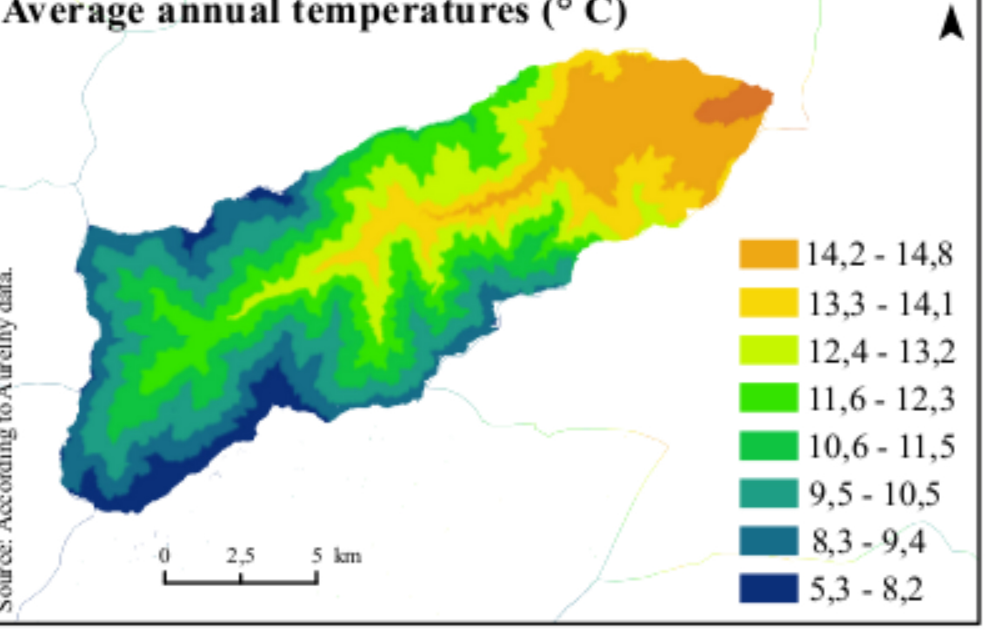

$$
\begin{array}{|l}
\hline \\
\hline
\end{array}
$$

Ombrothermic types
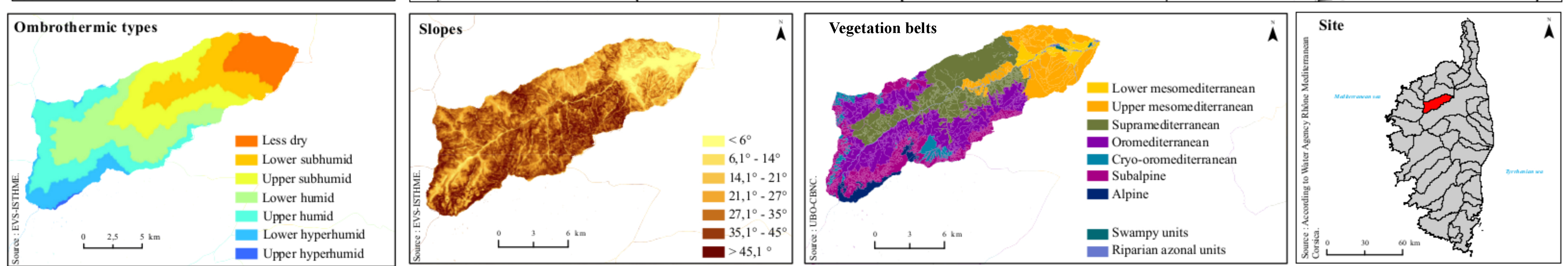

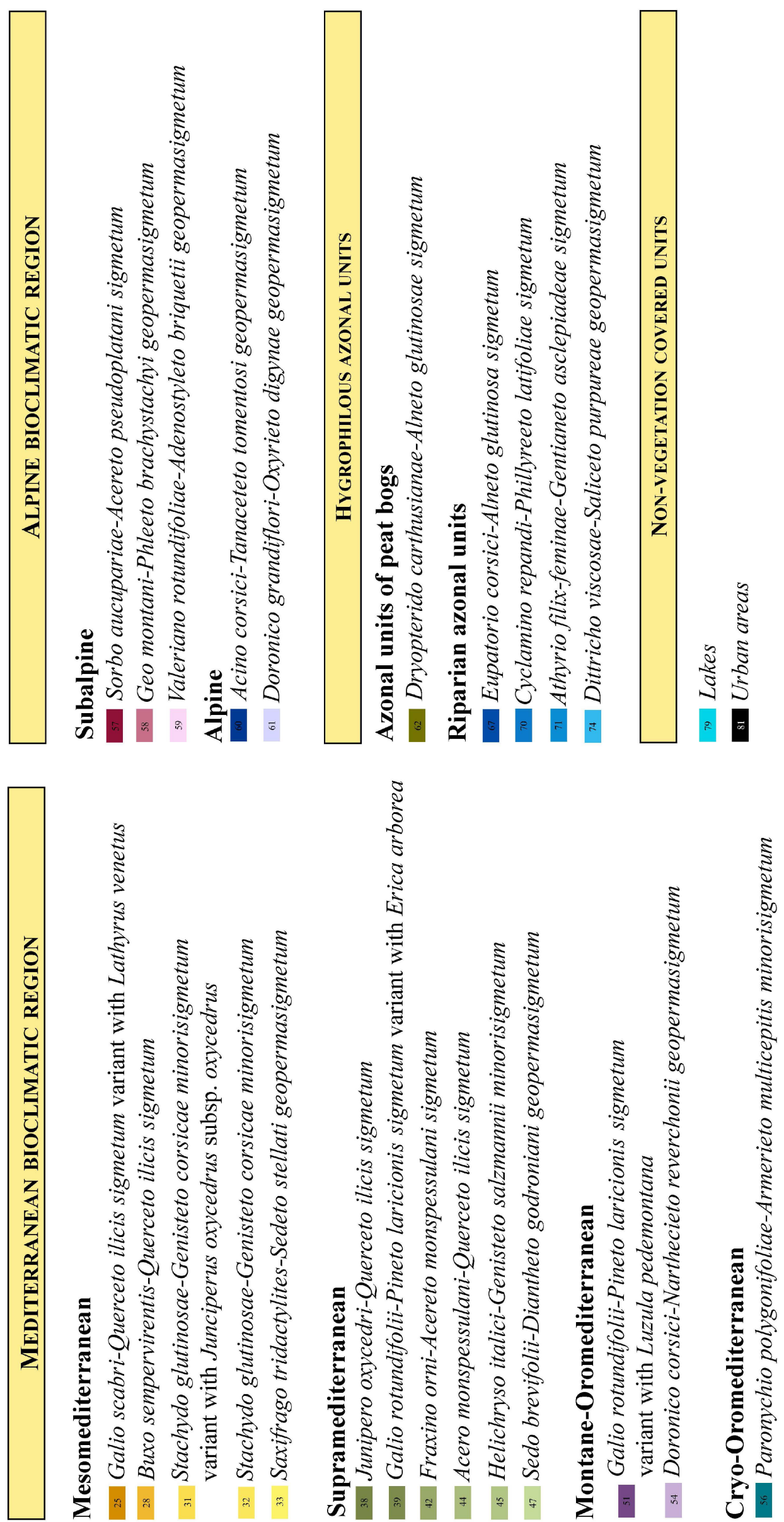
- for riparian azonal units, the main difficulty arises with altitude, due to narrow streams. They are represented by polygons and not by lines, in order to keep an homogeneus treatment of objects and to facilitate the analyzes.

During mapping work, several difficulties were raised:

- locating and interpreting the vegetation series of wooded slopes with limited access (Asco valley, Niolu valley, Capi Corsu and Castagniccia...). Since landmarks are rare in forests, the location, interpretation and delimitation of landscape features are often difficult, which is a source of potential error;

- mapping of series developed on rock faces. The horizontal projection of series colonizing vertical surfaces makes their individualization random. This is the case for rocky cliffs geopermaseries.

In these cases, it was chosen to photo-interpret them by taking into account the adjacent vegetation. The GPS integrated digital tablet (integrating Scan 25 and orthophotographs) was useful to overcome these difficulties.

As mapping vegetation series is an interpretation of landscape made by an observer, the limits and perception of vegetation units may vary. The map represents a synthetic tool where all the information observed cannot be transcribed. This is the case for permaseries of screes and rock outcrops, which are expressed within a vegetation series and whose small area make them not visible on the map.

A solution would have been to georeference these punctual units by GPS and to create a separate layer of information, before overlapping them on the map of objects. This option was not chosen for two reasons:

- homogenization: unlike coastal, thermomediterranean and mesomediterranean belts where the sectors are accessible, the problem arises with altitude. The distribution of these data would have been heterogeneous on mapped areas;

- readibility of the map: for sectors comprising a large number of point units, the readibility of map would have been limited due to the overload of information;

- homogeneity of grain of information.

Some sigmetal units that are expressed in a linear or a punctual way have been represented on the map. This is the case of the riparian azonal units of high altitude characterized by narrow rivers, which may appear to be over-represented in terms of proportional area. This technical mapping problem can be avoided depending on the scale of approach and the choices made regarding the area of the smallest mapped object. The tests carried out showed that the area of the smallest mapping object was 0,25 ha. Such amount has the advantage of being able to represent serial units of small area, especially in environments under strong ecological constraints (shorelines and rock massifs at high altitude).

If vegetation maps remain actual for a period of about five years, vegetation series maps are timeless. The definition of tessellar envelopes, or individuals of vegetation series, constitutes a stable ecological envelope in time and space $[63,64,69]$. From such maps, it is possible to obtain thematic maps, such as mapping of vegetation belts $[52,53]$.

The 1: 25,000 scale is a fine and precise map scale. Giacomini (1961) pointed out that the preferable scale for mapping an entire country was 1:200,000, since the 1: 100,000 would slow down its realization and would be very time consuming. In the case of the highly overlapping series (especially, climatophilous series), the 1:25,000 scale makes it possible to clearly visualize 
their cartographic distribution, but this is not the case for coastal zones. The coastal azonal units develop linearly and are not easily visible at $1: 25,000$. Our choice was therefore a mapping rendering between 1: 10,000 and 1: 13,000.

The delimitation of vegetation series and geoseries is realized by a manual segmentation. The first versions of the «white» underlayer or ecological underlayer for Corsica are only available since the end of 2013, and the improvement tests were only carried out in 2014. The ecological white underlayer has therefore not been used, but constitutes a research perspective.

Each valley and massif have its own bioclimatic, geomorphological and geomorphological identity, providing an ecological singularity. Causal and dynamic comparative analysis of vegetation series between sectors will make it possible to compare vegetation systems according to major entities. That is matching the concept of a functional landscape cell. These entities represent current landscape elements, characterized by a main economic function, which is sufficiently durable and has contributed to shaping its physiognomy and biological value.

\section{REFERENCES}

1. Archambault, M., Lhénaff, R., Vanney, J.-R., 1999, Documents et méthodes pour le commentaire de cartes (géographie et géologie), Premier fascicule, Principes généraux, Armand Colin, Paris.

2. Bacchetta, G., Bagella, S., Biondi, E., Farris, E., Filigheddu, R., Mossa, L., 2009, Vegetazione forestale e serie di vegetazione della Sardegna (con rappresentazione cartografica alla scala 1:350.000), Fitosociologia, 46: 3-82.

3. Bailey, R.-G., 1985, The factor of scale in ecosystem mapping, Environmental Management, 9: 271-276.

4. Barbero, M., Ozenda, P., 1979, Carte de la végétation potentielle des Alpes piémontaises à $1 / 400000$ (vegetazione potenziale degli Alpi Piemontese), Documents de cartographie Écologique, XXI: 139-162.

5. Bartoli, M., Largier, G., Abgrall, S., Luxcey, E., 1999, Une base cartographique de données phytoécologiques issue des relevés de catalogue de types de stations forestières, Revue Forestière Française, 1: 47-56.

6. Béguin, C., 1998, De l'utilisation des cartes phytosociologiques pour l'établissement des concepts de paysages végétaux, Saussurea, 29: 149-165.

7. Béguin, C., 2003, De l'usage des cartes phytosociologique et géomorphologique pour la conceptualisation des unités de paysage végétal (Sigmeta) exemple dans la région de Lona (Valais - Suisse), Documents Phytosociologiques, XX: 155-166.

8. Béguin, C., 2009, Carte des paysages végétaux de la région Lona-Sasserneire (Valais), Bulletin Murithienne, 126: $53-62$.

9. Béguin C., Géhu, J.-M., Hegg, O., 1979, La symphytosociologie: une approche nouvelle des paysages végétaux, Documents phytosociologiques, IV: 49-69.

10. Biondi, E., 2011, Phytosociology today: methodological and conceptual evolution, Plant Biosystems, 145: 19-29.

11. Biondi, E., 2012, Phytosociologie paysagère et évaluation de l'état de conservation des habitats. (Communication), «La cartographie de la végétation d'Europe»: Méthodologies de cartographie phytosociologique en Europe: approches symphytosociologique et géosymphytosociologique - Synthèse bibliographique, 17-19 octobre 2012.

12. Biondi, E., Calandra, R., Gigante, D., Pignatelli, S., Rampiconi, E., Venanzoni, R., 2002, Il paesaggio vegetale della provincia di Terni, Arti grafiche Iezzi, Terni.

13. Biondi, E., Casavecchia, S., Pesaresi S., 2011, Phytosociological synrelevés and plant landscape mapping: From theory to practice, Plant Biosystems, 145: 261-273

14. Biondi, E., Colosi, L., 2005, Environmental quality: An assessment based on the characters of the plant landscape, Plant Biosystems, 139: 145-154. 
15. Biondi, E., Filigheddu, R., Farris, E., 2001, Il Paesaggio vegetale della Nurra (Sardegna nord-occidentale). Pavia, Società italiana di fitosociologia, Fitosociologia, 38: 3-105.

16. Biondi, E., Filigheddu, R., Farris, E., 2004, Cartography and diachronic analysis of the vegetation of S'Ena Arrubia Lagoon (Centre-Western Sardinia), Fitosociologia, 41: 109-116.

17. Bioret, F., Gourmelon, F., 1999, Cartographies des milieux naturels et semi-naturels de Corse du Sud, https://cybergeo.revues.org/4912.

18. Bioret, F., Gourmelon, F., Culioli, J.-M., 2000, Mise au point d'une méthode de cartographie de la végétation terrestre des îlots marins en réserve naturelle, Revue Conserv'Actions: 9-13.

19. Bioret, F., Dominici, J.-M., Sturbois, A., 2008, Typologie et cartographie de la végétation terrestre de la Réserve Naturelle de Scandola. Rapport de la mission effectuée du 15 au 21 avril 2007, Parce Naturel Régional de Corse, Université de Bretagne Occidentale, Corté.

20. Bioret, F., Dominici, J.-M., Sturbois, A., 2009, Évolution de la végétation terrestre de la Réserve Naturelle de Scandola (Haute-Corse) entre 1984 et 2007, Bulletin de la Société des Sciences Historiques et Naturelles de la Corse, 728-729: 63-68.

21. Biotope, 2006, Inventaire et cartographie des habitats naturels du site Natura 2000 FR9400568 «Cap Corse nord \& îles Finocchiarola, Giraglia, Capense», Étude réalisée pour le compte de la Direction Régionale de l'Environnement de Corse. Bastia.

22. Blasi, C., Carranza, M.-L., Frondoni, R., Rosati, L., 2000, Ecosystem classification and mapping: a proposal for Italian landscapes, Applied Vegetation Science, 3: 233-242

23. Blasi, C., Filibeck, G., Frondoni, R., Rosati, L., Smiraglia, D., 2004, The map of the vegetation series of Italy, Fitosociologia, 41: 21-25.

24. Blasi, C. (coord.), 2010, La vegetazione d'Italia, con carta delle serie di vegetazione in scale 1:500.000, Palombi editori. Roma.

25. Blasi, C., Frondoni, R., 2011, Modern perspectives for plant sociology: The case of ecological land classification and the ecoregions of Italy, Plant Biosystems, 145: 30-37.

26. Blasi, C., Capotorti, G., Frondoni, R., 2005, Defining and mapping typological models at the landscape scale, Plant Biosystems, 139: 155-163.

27. Bonis, A., Ichter, J., Bouzillé, J.-B., 2012, Why and how setting up a national vegetation dataset in France? The project VegFrance, 47th Congress of the Italian Society for Vegetation Science «Opportunities and Challenges for Vegetation Science in a Changing World », 12-14 September 2012, Perugia (Italy).

28. Brossard, T., Wieber, J.-C., 2008, Paysage et information géographique, Lavoisier / Hermes. Paris.

29. Capelo, J., Mesquita, S., Costa, J.-C., Ribeiro, S., Arsénio, P., Neto, C., Monteiro-Henriques, T., Aguiar, C., Honrado, J., Espirito-Santo, D., Lousa M., 2007, A methodological approach to potential vegetation using GIS techniques and phytosociological expert-knwoledge: application to mainland Portugal, Phytocoenologia, 37: 399-415.

30. Catorci, A., Orsomando, E., Silvi, B., 1995, Il paesaggio vegetale del foglio nocera umbra N. 324 della carta d'italia I.G.M., un scala 1: 50 000, Colloques Phytosociologiques - Fitodinamica, XXIV: 665-673.

31. Cauvin, C., Escobar, F., Serradj, A. 2007, Cartographie thématique 1 : une nouvelle démarche, Information Géographique et Aménagement du Territoire, Hermes-Science, Lavoisier. Paris.

32. Clair, M., Gaudillat, V., Hérard K., 2005, Cartographie des habitats naturels et des espèces végétales appliquées aux sites terrestres du réseau Natura 2000 (Guide méthodologique), Muséum National d'Histoire Naturelle et Fédération des Conservatoires botaniques nationaux. Paris.

33. Conan, S., Faggio, G., Massoni, C., 2010, Document d'objectifs du site Natura 2000 de « Pinarellu : dunes et etangs de Padulatu et Padulu Tortu»(FR9400606), Les Amis du Parc Naturel Régional de Corse (AAPNRC)/CEN Corse et CELRL, Bastia.

34. Conservatoire du Littoral (C.D.L.), 2010, Document d'objectifs du site Natura 2000 «Campo dell'Oro» (FR 9400619), Plan de gestion du site du Conservatoire du littoral « Ricantu », Conservatoire du littoral, Bastia.

35. Delay, F., 2011, Cartographie des habitats naturels du site Natura 2000 FR9400576 : Massif du Cinto, partie Corscia, Biotope, Direction Régionale de l'Environnement, de l'Aménagement et du Logement de Corse. Borgo.

36. Delbosc, P., 2015, Phytosociologie dynamico-caténale des végétations de la Corse: méthodologies typologique et cartographique, Université de Bretagne Occidentale, Brest, France. 
37. Delbosc, P., Bioret, F., Panaïotis, C., 2015a, Les séries de végétation de la vallée d'Asco (typologie et cartographie au $1: 25$ 000), Ecologia mediterranea, 41: 5-87.

38. Defaut, B., 2001, Carte de la végétation de la France, Matériaux entomocénotiques, 6: 113-121.

39. Dobremez, J.-F., Ozenda, P., Tonnel, A., Vigny, F., Gensac, P., Pautou, G., Richard, L., 1974, Carte de la végétation potentielle des Alpes Nord-Occidentales (partie française), Documents de cartographie écologique, XIII: 9-27.

40. Dupias, G., 1963, Carte de la végétation de la France, notice sommaire, Centre National de la Recherche Scientifique, 80 et $81.21 \mathrm{pp}$.

41. Dupias, G., Gaussen, H., Izard, M., Rey, P., 1965, Carte de la végétation de la France, N 80-81, Corse. (Carte au 1:200 000 ${ }^{\text {ème }}$; Notice sommaire par G. Dupias), Centre National de la Recherche Scientifique, Service de la Carte de la Végétation, Toulouse), Toulouse, France.

42. Dupias, G., Isard, M., Monserrat, P., 1982, Carte de la végétation de la France, Feuille 76, Luz. CNRS, Paris.

43. Eggenberg, S., Dalang, T., Dipner, M., Mayer, C., 2001, Cartographie et évaluation des prairies et pâturage secs d'importance nationale, Office fédéral de l'environnement des forêts et du paysage, Rapport technique, cahier de l'environnement, Berne.

44. Emberger, L., 1961, Évolution, principes actuels et problèmes de la technique cartographique pratiquée au service de la carte des groupements végétaux. Méthodes de la cartographie de la cartographie de la végétation, Colloque Internationaux du Centre National de la Recherche Scientifique, XCVII: 211-146.

45. Emberger, L., Gounot, M., 1963, Séminaire de méthodologie phyto-écologique et phyto-géoographique, Centre d'études phytosociologiques et écologiques du C.N.R.S, 18-23 mars 1963, Montpellier (France).

46. Etlicher, B., Mazagol, P.-M., Sacca, C., Fayeaux, F., 2013, Recherches concernant la cartographie nationale des habitats naturels et semi-naturels, la construction du fond écologique. Rapport d'étape, Environnement Ville et Société, Université Jean Monnet Saint-Étienne, Ministère de l'Écologie, du Développement durable et de l'Énergie, Stratégie nationale pour la biodiversité.

47. Facioni, L., 2012, Classificazione ecologica territoriale e serie di vegetazione: i querceti termofili del settore Tirrenico dell'Appennino centrale, Sapienza Università di Roma, Dottorato di Ricerca in Scienze Ecologiche, Roma, Italy.

48. Faliński, J.-B., Pedrotti, F., 1990, The vegetation and dynamical tendancies in the vegetation of Bosco Quarto, Promontorio del Gargano, Italy, Braun-Blanquetia, 5: 1-31.

49. Gamisans, J., 1975, La végétation des montagnes corses, Thèse d'État, Université de Marseille, France.

50. Gamisans, J., 1991, La végétation de la Corse, Conservatoire et jardin botaniques de la ville de Genève, réédité en 1999, Édisud. Genève, Suisse.

51. Gamisans, J., 2010, Le paysage végétal de la Corse, Albiana, Ajaccio, France.

52. Gamisans, J., Grüber, M., 1979, La végétation du Niolu (Corse), Ecologia Mediterranea, 4: 141-156.

53. Gamisans, J., Gruber, M., Claudin, J., Casanova, J.-B., 1981, Carte de la végétation du Haut-Vénecais au 1/25 000, Ecologia Mediterranea, 7: 85-98.

54. Gamisans, J., Murracciole, M., 1984, La végétation de la Réserve Naturelle de la presqu'île de Scandola (Corse). Étude phytosociologique et cartographie au 1/10 000 ${ }^{\mathrm{e}}$, Ecologia Mediterranea, 10: 159-205.

55. Gaussen, H., 1933, Géographie des plantes, Armand Colin, Paris, France.

56. Gaussen, H., 1936, Le choix des couleurs dans les cartes botaniques, Bulletin de la Société Botanique de France, 83: $374-480$

57. Gaussen, H., 1938, Étages et zones de végétation de la France (commentaire des cartes 26, 2-3-4 de l'atlas de France), Ann. Géogr. (Paris), $47^{\mathrm{e}}$ année, France.

58. Gaussen, H., 1954, Géographie des plantes, 2ème édition, Colin, Paris, France.

59. Gaussen, H., 1961a, L'emploi des couleurs dans la cartographie de la végétation. Méthodes de la cartographie de la végétation, Comptes rendus de l'Académie des sciences, 224: 450-452.

60. Gaussen, H., 1961b, L'emploi des couleurs pour la cartographie de la végétation. Méthode de la Cartographie de la végétation, Colloques internationaux du CNRS, Édition du CBNRS, Toulouse, XCVII: 137-145.

61. Géhu, J.-M., 1976, Sur les paysages végétaux, ou sigmassociations des prairies salées du Nord-Ouest de la France, Document Phytosociologique, 15-18: 57-62.

62. Géhu, J.-M., 1977, Le concept de sigmassociation et son application à l'étude du paysage végétal des falaises atlantiques françaises, Vegetatio, 34: 117-125. 
63. Géhu, J.-M., 1979a, Pour une approche nouvelle des paysages végétaux : la symphytosociologie, Bulletin de la Société Botanique du Centre-Ouest, 126: 213-223.

64. Géhu, J.-M., 1979b, Carte symphytosociologique de la végétation naturelle potentielle du Nord de la France, Centre Régional de Phytosociologie, Bailleul, France.

65. Géhu, J.-M., 2004, La symphytosociologie trente ans plus tard (1973-2003) Concepts, systematisation, applications, Bulletin de la Société Botanique du Centre-Ouest, 35: 63- 80.

66. Géhu, J.-M., 2006, Dictionnaire de sociologie et synécologie végétales, Édition J. Cramer, Berlin, Stuttgart.

67. Géhu, J.-M., Biondi, E., 1994, Végétation du littoral de la Corse : essai de synthèse phytosociologique, Braun-Blanquetia, 13: 1-149.

68. Géhu, J.-M., Géhu-Franck, J., 1981, Essai d'objectivation de l'évaluation biologique des milieux naturels. Exemples littoraux. In: Géhu J.-M., Pelt, J.-M., L’évaluation biologique du territoire par la méthode des indices biocœnotiques, Institut Européen d'Ecologie, Metz: 75-184.

69. Géhu, J.-M., Rivas-Martínez, S., 1981, Notions fondamentales de phytosociologie. Berichte der Internationalen Symposien der Internationalen Vereinigung für Vegetationskunde, Syntaxonomie: 5-33.

70. Giacomini, V., 1961, Le problème du choix des échelles en cartographie de la vegetation. Méthodes de la cartographie de la végétation, Comptes rendus de l'Académie des sciences, 224: 127-135.

71. Gianguzzi, L., Spennati, B., La Mantia, A., 2007, La carta della vegetazione di Monte Carcaci, Sito d'Interesse Comunitario dei Monti Sicani (Sicilia centro-occidentale) (p. 88). Atti $43^{\circ}$ Congresso Società Italiana di Scienza della Vegetazione, Riassunti, Ancona 25-27 Giugno 2007.

72. Gourmelon, F., Sauve, L., Bioret, F., 2005, Potentialités de l'imagerie satellitaire SPOT 5 pour la cartographie de la végétation terrestre: application à l'île d'Ouessant (Finistère), Revue européenne de Géographie, 325: 1-15.

73. Küchler, A.-W., 1988, Aspects of Maps, Handbook of vegetation science, 10: 97-1040

74. Lambinon, J., Pironet, F., 1984, La végétation des rochers littoraux de la presqu'île de la Revellata, Corse, Webbia, 38:733-746.

75. Lazare, J.-J., 2009, Phytosociologie dynamico-caténale et gestion de la biodiversité, Acta Botanica Gallica, 156: 46-61.

76. Loidi J., 1991, Vegetation series: its use for small scale geobotanical mapping. Phytocœnosis, Cartographiae Geobotanicae, 2: 119-122.

77. Loidi, J., Bascones, J.-C., 2006, Memoria del mapa de series de végétacion de Navarra, Gobierno de Navarra, España.

78. Loidi, J., Biurrun, I., Campos, J.-A., García-Mijangos, I., Herrera, M., 2011, La vegetacion de la Comunidad Autonoma del Pais Vasco, Leyendo del mapa de series de vegetacion a escala $1: 50.0000$, Laboratorio de Botanica, Depto. De Biologia Vegetal y Ecologia, España..

79. Lorenzoni, C., Géhu, J.-M., Lahondère, C., Paradis, G., 1993, Description phytosociologique et cartographique de la végétation de l'étang de Santa Giulia (Corse du Sud), Bull. Soc. Bot. Centre-Ouest, 24: 121-150.

80. Lorenzoni, C., Paradis, G., 1996, Description phytosociologique et cartographique de la végétation des zones humides du golfe de Rondinara (Corse du Sud), Bulletin de la Société Botanique du Centre-Ouest, 27: 151178.

81. Lorenzoni C., Paradis G., 2000, Bull. Soc. Bot. Centre-Ouest, 31: 207-256.

82. Luque, S., Maréchal, D., Mikolajczak, A., Isenmann, M., Sanz, T., 2014, Modélisation des compartiments phyto-écologiques des milieux ouverts d'altitude par la théorie des graphes et les modèles de distribution d'espèces, Programme CarHAB - Volet modélisation des milieux ouverts d'altitude, Grenoble, France.

83. Mobaied, S., Machon, N., Lalanne, A., Riera, B., 2015, The Spatiotemporal Dynamics of Forest-Heathland Communities over 60 Years in Fontainebleau, France, Journal of GeoInformation, 4: 957-973.

84. Molinier, R., 1959, Étude des groupements végétaux terrestres du Cap Corse, Bulletin du museum d'histoire naturelle de Marseille, XIX: 5-75.

85. Molinier, R., 1962, Notice explicative de la carte des groupements végétaux terrestres et des biocénoses marines du Cap Corse, I.G.N. Paris, France.

86. Office de l'Environnement de la Corse (O.E.C.), 2006, Documents d'objectifs Natura 2000 du site FR 9400617 «Dunes de Prunete-Canniccia», Direction Départementale de l'Agriculture et de la Forêt de HauteCorse, Office de l'Environnement de la Corse Département «Ecosystèmes Terrestres», Corte, France. 
87. Ozenda, P., 1963, Principes et objectifs d'une cartographie de la végétation des Alpes à moyenne échelle, Documents de cartographie écologique Grenoble, XVI: 5-18.

88. Ozenda, P., 1964, Biogéographie végétale, Editions Doin, Paris, France.

89. Ozenda, P., 1982, Les végétaux dans la biosphère, Doin Editeurs, Paris, France.

90. Ozenda, P., 1985, La végétation de la chaîne alpine dans l'espace montagnard européen, Masson, Paris, France.

91. Ozenda, P., 1986, La cartographie écologique et ses applications, Masson, Paris, France.

92. Ozenda, P., Lucas, M.-J., 1987, Esquisse d'une carte de la végétation potentielle de la France à 1:500 000, Documents de cartographie écologique, XXX: 49-80.

93. Ozenda, P., Wagner, H., 1975, Les séries de végétation de la chaîne alpine et leurs équivalences dans les autres systèmes phytogéographiques, Documents de cartographie écologique, XVI: 49-64.

94. Paradis, G., 1992, Étude phytosociologique et cartographique de la végétation du marais de Tizzano (Corse occidentale) et de son pourtour, Bull. Soc. Bot. Centre-Ouest, 23: 65-94.

95. Paradis, G., Feral, C., Passigny-Hernandez, C., Nicolau, J., Carles, S., 2014, Paysage végétal de la vallée du Baracci et du nord du golfe de Valinco (sud-ouest de la Corse): phytosociologie et carte de la végétation, Journal de Botanique, Société de Botanique Française, 67: 9-105.

96. Paradis, G., Lorenzoni, C., Tomasi, J.-C., 1995, Étude phytosociologique et cartographique de la végétation des pourtours du lac de Creno. Impacts dus aux animaux et au piétinement et influence de la pose de clôtures, Travaux Scientifiques du Parc Naturel Régional et des Réserve naturelle de Corse, 54: 11-64.

97. Paradis, G., Maurin, A., Piazza, C., 2010, Étude phytosociologique et cartographie de la végétation du site Natura 2000 "Ricanto-Campo dell'Oro" (Ajaccio, Corse), Bull. Soc. Bot. Centre-Ouest, 41: 139-232.

98. Paradis, G., O’Deye-Guizien, K., Piazza, C., 2013, Étude floristique, phytosociologique et cartographique des zones humides, Journal Botanique de la Société Botanique de France, 63: 15-54.

99. Paradis, G., Piazza, C., 1992, Description phytosociologique et cartographique de la végétation de deux sites dégradés du Golfe de Valinco (Corse): Campomoro et Tenutella, Colloques Phytosociologiques, XIX, "Végétation et qualité de l'environnement côtier en Méditerranée ", Cagliari 24-29 octobre 1989: 341-370.

100. Paradis, G., Piazza, C, 1993, Étude phytosociologique et cartographique de la végétation des dunes de Tizzano, de Tralicetu et de la Plage d'Argent (sud-ouest de la Corse), Bull. Soc. Bot. Centre-Ouest, 24: 219266.

101. Paradis, G., Piazza, C., 1994, Étude phytosociologique et cartographique du littoral sableux du site de La Rondinara (Sud de la Corse), Res Mediterranea, 1: 25-52.

102. Paradis, G., Piazza, C., 1995, Étude phytosociologique et cartographique des cordons de galets de Crovani et du nord-est de Galéria (Corse occidentale), Bull. Soc. Bot. Centre-Ouest, 26: 45-98.

103. Paradis, G., Piazza, C., 1999, Étude phytosociologique et cartographique de la végétation de plages des environs de Cargèse (Corse occidentale): Arone, Chiuni, Peru, Capizollu, Stagnoli, Documents Phytosociologiques, XIX: 163-217.

104. Paradis, G., Piazza, C., Pozzo Di Borgo, M.-L., 2004, Paysage végétal du site de Prunete-Canniccia (côte orientale corse) proposé pour le Réseau Natura 2000, Bulletin de la société des sciences historiques et naturelles de Corse, 706-707: 7-91.

105. Paradis, G., Piazza, C., Ravetto, S., 2002, Paysage végétal du site de Canna-Gradugine, Bulletin de la société des sciences historiques et naturelles de Corse, 698-701: 43-166.

106. Paradis, G., Pozzo Di Borgo, M.-L., 2000, Étude phytosociologique et phytocartographique du "delta du Stabiacciu" (Porto-Vecchio, Corse), site proposé pour le réseau Natura 2000, Colloque Phytosociologique, Phytosociologie sigmatiste, XXVI: 595-662.

107. Paradis, G., Tomasi, J.-C., 1991, Aperçus phytosociologique et cartographique de la végétation littorale de Barcaggio (Cap Corse, France): rochers, dunes, étangs et dépressions, Documents Phytosociologiques, NS XIII: $175-208$.

108. Pedrotti, F., 1997, Les données de la phytosociologie pour la cartographie géobotanique, Colloques phytosociologiques, XXVII: 503-541.

109. Pedrotti, F., 1998, La cartographie géobotanique des biotopes du Trentin (Italie), Écologie, 29: 105-110.

110. Pedrotti, F., 2004, Cartographia Geobotanica, Pitagora Editrice Bologna, Italy.

111. Pedrotti, F., 2013, Plant and vegetation mapping, Springer, Italy.

112. Pedrotti, F., Gafta, D., 2003, Approccio fitogeografico alla distinzione di megageoserie di vegetazione nelle 
Alpi del Trentino-Alto Adige (con carta: 1:250.000), Centro di Ecologia Alpina, 30: 1-18.

113. Peralta de Andrés, J., 2010, Vegetación Potencial de Navarra 1: 25000 Comarca Agraria II : Pirineos. Departemento de Desarollo Rural y Medio Ambiente y Administracion Local, Gobierno de Navarra, Pamplona, España: http://www.cfnavarra.es/agricultura/informacion_agraria/MapaCultivos/htm/situacion.htm

114. Pesaresi, S., Biondi, E., Casavecchia, S., Catorci, A., Foglia, M., 2007, Il geodatabase del sistema informativo vegetazionale delle Marche, Fitosociologia, 44: 95-101.

115. Piazza, C., Paradis, G., 1994, Étude phytosociologique et cartographique d'un site littoral sableux en voie de dégradation anthropique : le cordon de Balistra (Sud de la Corse), Bull. Soc. Bot. Centre-Ouest, 25: 59-98.

116. Piazza, C., Paradis, G., 1995, Description phytosociologique et cartographique de la végétation du site protégé de Roccapina (Corse, France): Dune et zone humide, Documents phytosociologiques, XV: 211-233.

117. Piazza, C., Paradis, G., 2000, Description phytosociologique et cartographique de la végétation du cordon littoral de Palo (côte orientale de la Corse), Bull. Soc. Bot. Centre-Ouest, 31: 115-170.

118. Pinto-Gomes, C., Rosendo, J., Paiva-Ferreira, R., Sariva, R., Martins, E., 2003, O Papel da Cartografia da Vegetação no Ordenamento Florestal: O Caso do Sudoeste Alentejano e Barlavento Algarvio, Departamento de Ecologia, Universidade de Évora, Rua Romão Ramalho. Portugal.

119. Pozzo Di Borgo, M.-L., Ravetto, S., Lorenzoni, C., Paradis, G., 2002, Description phytosociologique et cartographie de la végétation du site d'Arasu (sud-est de la Corse), proposé pour le Réseau Natura 2000. (+ 1 carte et 7 photos h.t.), Travaux Scientifiques du Parc Naturel Régional et des Réserve naturelle de Corse, 60: $1-56$.

120. Pozzo Di Borgo, M.-L., Ravetto, S., Lorenzoni, C., Paradis, G., 2003, Paysage végétal du site de Benedettu (Corse), proposé pour le Réseau Natura 2000, Travaux Scientifiques du Parc Naturel Régional et des Réserve naturelle de Corse, 61: 81-134

121. Rey, P., 1961, De la clarté en toute chose, même en cartographie de la végétation, $97^{\mathrm{e}}$ Colloque international de la recherche scientifique Paris CNRS: 283-288.

122. Rey, P., 2009, Histoire de la cartographie de la végétation en France, $C F C$, 199: 105-115.

123. Rivas-Martínez, S., 1976, Sinfitosociologia, una nueva metodologia para el estudio del paisaje vegetal, Anal. Inst. Bot. Cavanilles, 33: 179-188.

124. Rivas-Martínez, S., 1987a, Memoria del mapa de series de vegetación de España, Ministerio de Agricultura, Pesca y Alimentación, Editions I.C.O.N.A. Série Técnica, Madrid, España.

125. Rivas-Martínez, S., 1987b, Introduccion: Nociones sobre fitosociologia, biogeographia y bioclimatologia. In: Peinado-Lorca, M., Rivas-Martínez, S., (eds), La vegetacion de España, Madrid: 19-45.

126. Rivas-Martínez, S., 1982, Étages bioclimatiques, secteurs chorologiques et séries de végétation de l'Espagne méditerranéenne, Ecologia mediterranea, VIII: 275-288.

127. Roux, C., Thébaud, G., Bouzillé, J.-B., Bonis, A., Hennekens, S., 2015, Describing vegetation at the landscape level: "SYNPHYTO", a database designed for series and geoseries dataset within the VegFrance project. (communication). $24^{\text {th }}$ International workshop European Vegetation Survey «Typology and process as two complementary facets of vegetation survey and mapping - Vegetation in coastal and inland dunes and cliffs», 4 au 8 mai 2015, Rennes, (France).

128. Schwabe, A., 1989, Vegetation complexes of flowing-water habitats and their importance for the differentiation of landscapes units, Landscape Ecology, 2: 237-253.

129. Theurillat, J.-P., 1992a, Études symphytocœnologiques dans la région d'Aletsch (Valais, Suisse), Thèse de doctorat ès Sciences, Université de Berne, Suisse.

130. Theurillat, J.-P., 1992b, L'analyse du paysage végétal en symphytocœnologie: ses niveaux et leurs domaines spatiaux, Bulletin Écologique, 23: 83-92.

131. Tüxen, R., 1973, Vorschlag zur Aufnahme von Gesellschaftskomplexen in potentiell natürlichen Vegetationsgebieten, Acta Botanica Academia Hungarica, 19: 379-384.

132. Tüxen, R., 1978, Bemerkungen zu historischen, begrifflichen und methodischen Grundlagen der Synsoziologie, Ber. Int. Symp. Int. Vereinigung Vegetationsk: 3-11.

133. Tüxen, R., 1979, Sigmeten und Geosigmeten, ihre Ordnung und ihre Bedeutung für Wissenschaft. Naturschutz und Planung, Biogeographica, 16: 79-92.

134. Valle, F., 1985, Mapa de las series de vegetacion de Sierra-Nevada (España), Ecologia Mediterranea, 11: 183-199. 
135. Verclytte, C., 2012, Étude de la répartition d'Armeria soleirolii (Duby) Godron et des espèces exotiques envahissantes de Galéria à la Revellata (Corse). Contribution au diagnostic écologique du site Natura 2000 : «Porto / Scandola / Revellata / Calvi / Calanches de Piana », Conservatoire botanique national de Corse, Office de l'Environnement de la Corse, Institut Polytechnique Lasalle Beauvais, Corté, France.

136. Vigo, J., Carreras, J., Carrillo, E., Ferré, A., Font, X., Ninot, J.-M., Soriano, I., 1997, L'application des données phytosociologiques à la cartographie de la végétation, Colloques Phytosociologiques, XXVII: 543552.

137. Vinet, P., 2011, Cartographie des habitats naturels du Site Natura 2000 FR9400592 «Ventilègne, Trinité de Bonifacio, Fazzio », Biotope, DREAL de Corse, Borgo, France.

\section{CARTAREA FITOSOCIOLOGICĂ DINAMICO-CATENALĂ A CORSICĂI: O ABORDARE METODOLOGICĂ INDUCTIVĂ}

\section{(Rezumat)}

Programul naţional de cartare a vegetaţiei naturale şi seminaturale a Franței (CarHAB) a fost lansat în 2010 la iniţiativa Ministerului Ecologiei, Dezvoltării Durabile şi Energiei. Scopul acestui program este să implementeze un sistem informatic despre vegetaţia naturală şi seminaturală din Franţa, în vederea dezvoltării de instrumente pentru planificare teritorială, politici naţionale de conservare a naturii (strategia instituirii de arii protejate ...) şi angajamente europene (evaluarea stării de conservare a habitatelor de interes comunitar ...). Acest program se bazează pe metoda fitosociologiei peisagere şi dinamice, denumită şi fitosociologie dinamico-catenală. Această metodologie permite o analiza sistematică şi integrată a tuturor componentelor biotice şi abiotice, precum şi a complexităţii sistemelor ecologice ce compun peisajul vegetal.

Lucrarea de faţă prezintă metodologia cartării seriilor de vegetaţie şi geoseriilor, aplicată sub diverse forme de harţi sinfitosociologice din Europa. Obiectivele prezentului studiu au fost:

- să propună o abordare metodologică pragmatică şi precisă pentru cartarea seriilor şi geoseriilor de vegetaţie din Corsica la scara 1:25000;

- să ia în considerare aspectele ştiinţifice (scara de lucru, tipologia, straturile suprapuse, ...), tehnice şi semiologice (tonul şi saturaţia culorilor, formele de expresie, ...) legate de design-ul şi realizarea hărţilor. 